OPEN ACCESS

Edited by:

Zhijun Dong,

Yantai Institute of Coastal Zone Research (CAS), China

Reviewed by:

Julian Gutt,

Alfred Wegener Institute Helmholtz Centre for Polar and Marine Research

(AWI), Germany

Anja Schulze,

Texas A\&M University at Galveston,

United States

${ }^{*}$ Correspondence:

Regan Drennan

r.drennan@nhm.ac.uk; regan.drennan5@gmail.com

Specialty section: This article was submitted to

Marine Evolutionary Biology, Biogeography and Species Diversity, a section of the journal Frontiers in Marine Science

Received: 15 August 2020 Accepted: 01 December 2020 Published: 08 January 2021

Citation:

Drennan R, Dahlgren TG, Linse K and Glover AG (2021) Annelid Fauna

of the Prince Gustav Channel, a Previously Ice-Covered Seaway on the Northeastern Antarctic Peninsula.

Front. Mar. Sci. 7:595303.

doi: 10.3389/fmars.2020.595303

\section{Annelid Fauna of the Prince Gustav Channel, a Previously Ice-Covered Seaway on the Northeastern Antarctic Peninsula}

\author{
Regan Drennan ${ }^{1,2 *}$, Thomas G. Dahlgren ${ }^{3,4}$, Katrin Linse ${ }^{5}$ and Adrian G. Glover ${ }^{1}$ \\ ${ }^{1}$ Life Sciences Department, Natural History Museum, London, United Kingdom, ${ }^{2}$ Ocean and Earth Science, University of \\ Southampton, Southampton, United Kingdom, ${ }^{3}$ NORCE Norwegian Research Centre, Bergen, Norway, ${ }^{4}$ Department \\ of Marine Sciences, University of Gothenburg, Gothenburg, Sweden, ${ }^{5}$ British Antarctic Survey, Cambridge, United Kingdom
}

The Prince Gustav Channel is a narrow seaway located in the western Weddell Sea on the northeastern-most tip of the Antarctic Peninsula. The channel is notable for both its deep (>1200 m) basins, and a dynamic glacial history that most recently includes the break-up of the Prince Gustav Ice Shelf, which covered the southern portion of the channel until its collapse in 1995. However, the channel remains mostly unsampled, with very little known about its benthic biology. We present a preliminary account of the benthic annelid fauna of the Prince Gustav Channel in addition to samples from Duse Bay, a sheltered, glacier-influenced embayment in the northwestern portion of the channel. Samples were collected using an Agassiz Trawl, targeting megafaunal and large macrofaunal sized animals at depths ranging between 200-1200 m; the seafloor and associated fauna were also documented in situ using a Shallow Underwater Camera System (SUCS). Sample sites varied in terms of depth, substrate type, and current regime, and communities were locally variable across sites in terms of richness, abundance, and both taxonomic and functional composition. The most diverse family included the motile predator/scavenger Polynoidae, with 105 individuals in at least 12 morphospecies, primarily from a single site. This study provides first insights into diverse and spatially heterogeneous benthic communities in a dynamic habitat with continuing glacial influence, filling sampling gaps in a poorly studied region of the Southern Ocean at direct risk from climate change. These specimens will also be utilized in future molecular investigations, both in terms of describing the genetic biodiversity of this site and as part of wider phylogeographic and population genetic analyses assessing the connectivity, evolutionary origins, and demographic history of annelid fauna in the region.

\section{Keywords: polychaeta, Weddell Sea, species checklist, Southern Ocean, benthic, morphology, taxonomy}

\section{INTRODUCTION}

Ice shelves are vast, floating platforms of ice that form where continental ice sheets meet the ocean, fringing much of the Antarctic coastline and covering over 30\% of the Antarctic continental shelf (Barnes and Peck, 2008). Sub-ice shelf ecosystems thus constitute a significant portion of available benthic habitat in the Southern Ocean, though remain amongst the least known on the planet 
due to general inaccessibility and are at a direct risk of being lost due to climate change. Ice shelves are extensive along both sides of the Antarctic Peninsula, covering approximately $120,000 \mathrm{~km}^{2}$ of seafloor today (Cook and Vaughan, 2010). However, in recent decades the Antarctic Peninsula has experienced amongst some of the fastest regional warming on the planet (Vaughan et al., 2003), with substantial increases in both atmospheric and ocean temperatures (e.g., Meredith and King, 2005; Turner et al., 2005). These increases are largely thought to have contributed to the significant thinning, retreat and collapse of ice shelves along the Antarctic Peninsula over the past 60 years (Cook and Vaughan, 2010; Rignot et al., 2013; Etourneau et al., 2019), with significant losses including the collapse of the Larsen A and Prince Gustav Ice Shelves in 1995 (Rott et al., 1996), the Larsen B ice shelf in 2002 (Rack and Rott, 2004), and the calving of a massive $5,800 \mathrm{~km}^{2}$ iceberg from the Larsen C Ice Shelf in 2017 (Marchant, 2017).

Until its collapse in the early 1990s, the Prince Gustav Ice Shelf (PGIS) was the most northerly ice shelf on the Antarctic Peninsula, spanning the southern portion of the Prince Gustav Channel (PGC) (see Ferrigno et al., 2006), a deep, narrow seaway located on the inner continental shelf of the northwestern Weddell Sea that separates James Ross Island from the northernmost tip of the Antarctic Peninsula (see Figure 1). Broadly categorized as a fjord (Camerlenghi et al., 2001), the PGC consists of a discontinuous u-shaped glacial trough with steep sided walls and three over-deepened basins (approximately $900 \mathrm{~m}, 1000 \mathrm{~m}$, and $1200 \mathrm{~m}$ deep moving north to south), separated by two shallower sills (approximately $350 \mathrm{~m}$ and $600 \mathrm{~m}$ deep respectively) (Camerlenghi et al., 2001). The channel formed before the late Miocene and was progressively deepened by several advances of grounded glaciers during the Neogene and Quaternary periods (Nývlt et al., 2011), and with evidence of floating ice shelves from the end of the Pleistocene (Evans et al., 2005; Johnson et al., 2011).

In contemporary terms, the PGIS and other small ice shelves on the northeastern Antarctic Peninsula have been observed for a far longer period than many other Antarctic ice shelves; first visited over 170 years ago and mapped by the Swedish Antarctic Expedition 1901-1903 (Nordenskjöld and Andersson, 1905), these ice shelves are generally thought to have been in retreat since historical observations began, with the PGIS itself once contiguous with the Larsen A ice shelf until the mid 20th century (Cooper, 1997). In contrast to larger ice shelves that can remain stable over tens of thousands of years, these small northern ice shelves are at the climactic limit of ice shelf viability (Morris and Vaughan, 2003) and may therefore act as more sensitive indicators of recent climatic and oceanographic change (Pudsey et al., 2006), with evidence of periodic advance and retreat of ice shelves in the region throughout the Holocene, as demonstrated by several studies of data from sediment cores (e.g., Pudsey and Evans, 2001; Brachfeld et al., 2003; Pudsey et al., 2006). This includes a period of retreat during the mid-Holocene ( 5-2 ka) in which the PGIS was completely absent (Pudsey and Evans, 2001), though with break up and regrowth appearing to occur gradually over centuries as opposed to the decadal scale of changes to contemporary ice shelf extent (Pudsey et al., 2006).
Understanding the biology of previously ice covered habitats is important in the context of unprecedented ice loss along the Antarctic Peninsula. However, despite the dynamic glacial history of the channel, the biology of the PGC, both before and after ice shelf collapse, is virtually unknown. In May 2000, a number of geological and geophysical surveys of the PGC were conducted by the RVIB Nathaniel B. Palmer as part of a larger investigation of the seafloor exposed by the then recent 1995 break-up of the Larsen A ice shelf (Domack et al., 2001). Biological samples were also obtained from collected sediment, however, these sampling sites were restricted to the southern portion of the channel (see Blake, 2015). Furthermore, while a number of polychete specimens collected from this cruise have been included in several broader taxonomic publications (Blake, 2015, 2017, 2018), a summary of these samples and of the southern PGC benthic community is not currently available. In addition, no further biological investigations have taken place subsequent years, and the channel remains otherwise unsampled, which is not uncommon for the region, with the western Weddell Sea considered to be one of the most poorly sampled areas of the Southern Ocean (Griffiths et al., 2014).

Annelid worms, or polychetes, are amongst the most species rich groups in the Southern Ocean (Clarke and Johnston, 2003), and can represent a dominant component of Antarctic benthic assemblages in terms of both abundance and biomass (e.g., Gambi et al., 1997; Piepenburg et al., 2002; Hilbig et al., 2006; Sañé et al., 2012). Found across the Southern Ocean from intertidal to abyssal depths (Brandt et al., 2009), polychetes fill a diverse array of trophic guilds and functional groups on both hard and soft substrates (e.g., Gambi et al., 1997), and are thus both an important and informative group to consider when assessing the biology of Antarctic benthic ecosystems. The following report documents a preliminary overview of the benthic annelid fauna of the Prince Gustav Channel collected during the expedition JR17003a on board RSS James Clark Ross February-March 2018. Samples were collected using an Agassiz trawl from several sites along the northern portion of the channel including the deepest $(>1200 \mathrm{~m})$ basin of the PGC. In contrast to the more open channel, samples were additionally collected from Duse Bay, a sheltered, glacier influenced embayment located in the northwestern portion of the PGC. The aims of this study were to (1) characterize the annelid fauna of the PGC, a previously ice covered channel in the northwestern Weddell Sea and (2) examine spatial variation in annelid assemblages in this habitat by comparing samples from open and sheltered areas of the PGC.

\section{MATERIALS AND METHODS}

\section{Sample Sites and Sample Collection}

The annelid specimens examined in this study were collected using an Agassiz Trawl (AGT) during the expedition JR17003a on board the RRS James Clark Ross February-March 2018, which sampled the northern portion of the Prince Gustav Channel (PGC) situated on the northeastern tip of the Antarctic Peninsula. The three main sampling sites were as follows: (1) 


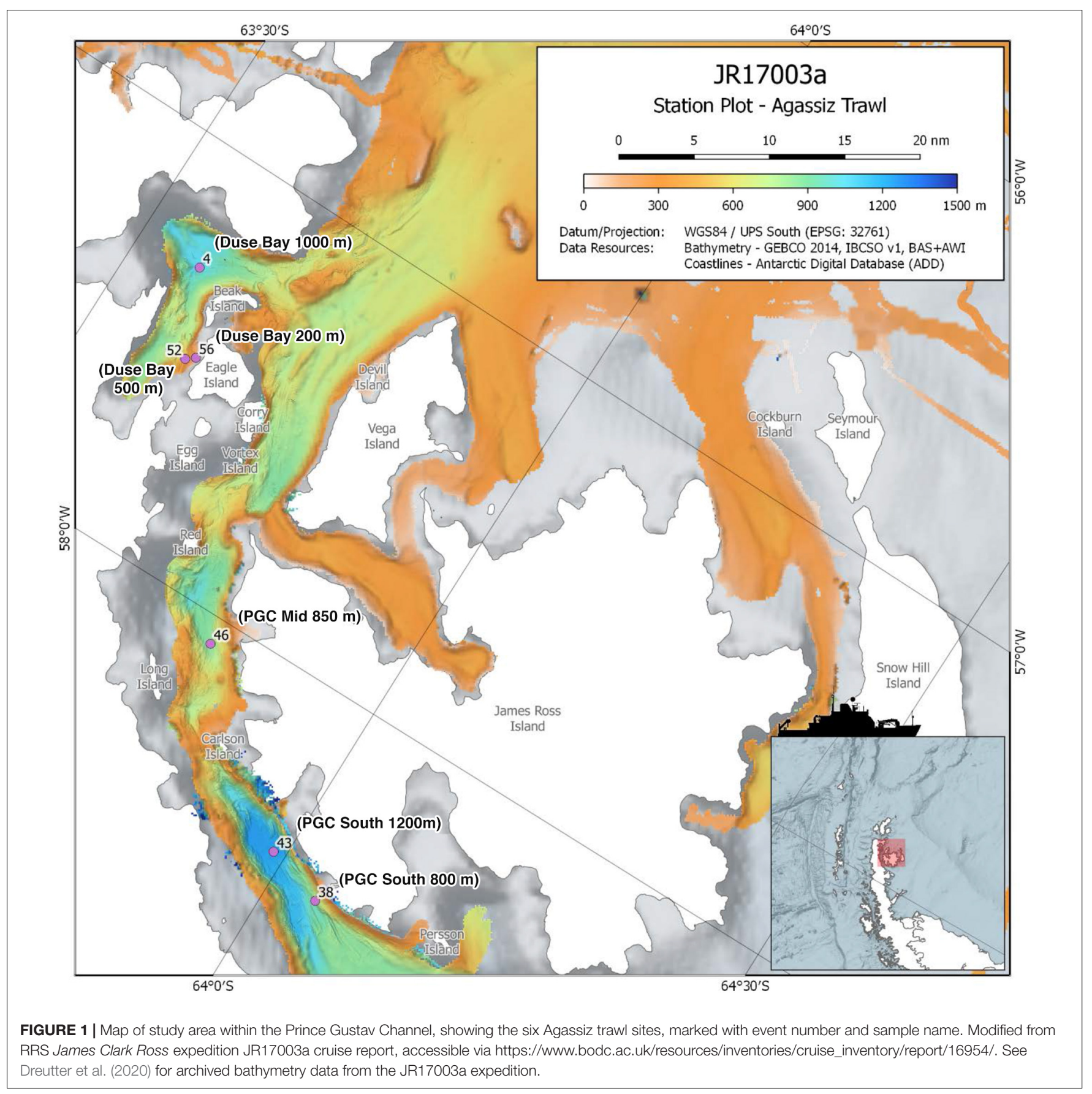

Duse Bay, a sheltered, glacier influenced bay located in the northwestern portion of the PGC; (2) PGC Mid, located in the main channel, including the second deepest basin of the PGC; (3) PGC South, the southernmost sample site, located in the main channel and including the deepest basin of the PGC (Figure 1).

Three trawling depths $(200 \mathrm{~m}, 500 \mathrm{~m}, 800 / 1000 \mathrm{~m})$ were initially planned for each of the main sampling sites, with an additional deep $1200 \mathrm{~m}$ trawl of the basin at PGC South. However, only at Duse Bay sites were all three trawling depths achieved, as 200 and $500 \mathrm{~m}$ sites in the channel proper were too influenced by boulders to deploy the AGT. In total, six successful AGT deployments between depths of $204 \mathrm{~m}$ and $1270 \mathrm{~m}$ were carried out across the three sites (Figure 1 and Table 1) and sorted on board for benthic fauna. The AGT apparatus used comprised of a $1 \mathrm{~cm}$ mesh with a mouth width of $2 \mathrm{~m}$, and once on the seabed was trawled at 1 knot for 5-10 min at each site. The AGT targeted macro- and megafaunal sized animals $1 \mathrm{~cm}$ and larger, though with some smaller animals additionally captured in the sediment retained in trawls.

A 'cold-chain' live sorting pipeline was followed on board, as outlined in detail in Glover et al. (2016). In summary, AGT 
TABLE 1 | Details of Agassiz Trawl stations within the Prince Gustav Channel sampled during the expedition JR17003a.

\begin{tabular}{|c|c|c|c|c|c|c|c|c|c|c|}
\hline $\begin{array}{l}\text { Event } \\
\text { no. }\end{array}$ & Site & Date & $\begin{array}{l}\text { Decimal } \\
\text { latitude }\end{array}$ & $\begin{array}{c}\text { Decimal } \\
\text { longitude }\end{array}$ & $\begin{array}{c}\text { Max } \\
\text { depth (m) }\end{array}$ & $\begin{array}{c}\text { No. of } \\
\text { individuals }\end{array}$ & $\begin{array}{c}\text { No. of } \\
\text { families }\end{array}$ & $\begin{array}{c}\text { No. of } \\
\text { morphospecies }\end{array}$ & $\mathbf{H}^{\prime}$ & J' \\
\hline 56 & Duse Bay 200 m & 2018-03-07 & -63.62531 & -57.48627 & 203.85 & 48 & 10 & 13 & 1.99 & 0.77 \\
\hline 52 & Duse Bay 500 m & 2018-03-07 & -63.61614 & -57.50349 & 483.01 & 99 & 19 & 32 & 2.76 & 0.80 \\
\hline 4 & Duse Bay 1000 m & 2018-03-01 & -63.57554 & -57.29537 & 1080.63 & 260 & 8 & 10 & 0.95 & 0.41 \\
\hline 46 & PGC Mid 850 m & 2018-03-06 & -63.80603 & -58.06523 & 869.95 & 126 & 8 & 21 & 2.33 & 0.76 \\
\hline 38 & PGC South 800 m & 2018-03-05 & -64.05515 & -58.47654 & 868.42 & 41 & 11 & 19 & 2.45 & 0.83 \\
\hline 43 & PGC South 1200 m & 2018-03-06 & -63.98811 & -58.42253 & 1271.42 & 24 & 3 & 4 & 0.84 & 0.60 \\
\hline
\end{tabular}

$H^{\prime}=$ Shannon-Weiner diversity index, J' = Pielou's Evenness.

sub-samples were carefully washed on 300 -micron sieves in cold filtered seawater (CFSW), and annelid specimens were picked from sieve residue, cleaned and maintained in CFSW, and relaxed in Magnesium Chloride solution prior to specimen photography. Specimens were imaged using Canon EOS600D cameras either with $100 \mathrm{~mm}$ Macro lens or through a Leica MZ7.5 microscope with SLR camera mount. Specimens were preliminary identified on-board to family level, numbered and recorded into a database, and fixed in $80 \%$ non-denatured ethanol. Samples that could not be fully sorted on board due to time restrictions were fixed in bulk for later sorting.

A Shallow Underwater Camera System (SUCS) (Nolan et al., 2017) comprised of a $1000 \mathrm{~m}$ fiber optic cable (allowing operation to $\sim 900 \mathrm{~m}$ ) and a tripod-mounted HD camera system was deployed at twelve stations along the PGC, ranging in depth from 200-800 m. SUCS deployments typically involved three consecutive transects spaced $100 \mathrm{~m}$ apart, with each transect consisting of 10 photos taken at $10 \mathrm{~m}$ intervals. Photos consisted of high resolution stills $(2448 \times 2050$ pixels $)$ covering approximately $0.51 \mathrm{~m}^{2}$ of seafloor (Almond, 2019). Four SUCS stations corresponded closely with AGT localities, providing a snapshot of the habitat heterogeneity in the vicinity of these samples and in situ images of some of the most common species encountered. A dataset of all JR17003a SUCS imagery can be accessed through the following doi: 10.5285/48DCEF16-6719-45E5-A3353A97F099E451 (Linse et al., 2020).

\section{Laboratory Sorting and Identification}

In the laboratory, remaining bulk-fixed samples were sorted and all specimens were re-examined using a Leica M216 stereomicroscope, and key morphological characters were imaged using a fitted Canon EOS600D camera. Specimens were identified to the best possible taxonomic level using original literature, specimen keys, and comparison with type specimen material from NHM collections. Where named species identifications were not possible, specimens were described as a morphospecies where the voucher number of a representative specimen is used as an informal species name for all specimens deemed to be the same species as the representative individual, e.g., Polynoidae sp. NHM_228. Where named species identifications were uncertain, the open nomenclature 'cf.' was used as a precautionary approach along with a representative voucher number, e.g., Antarctinoe cf. ferox NHM_232. Where specimens were fragmented, only fragments that clearly bore heads were counted and included in abundance records, as standard practice.

\section{Data Analysis}

Specimen data were assembled into a Microsoft Excel database, and data visualization and analyses were carried out using the software R v.3.6.2 (R Core Team, 2019) and the R package 'vegan' v.2.5-6 (Oksanen et al., 2019). Local diversity was assessed for each site using the Shannon-Wiener diversity index $\left(H^{\prime}\right)$ and Pielou's evenness (J') (Shannon and Weaver, 1949; Pielou, 1969). Figures were assembled and edited using Microsoft PowerPoint and Adobe Photoshop software.

Specimen data are included as supplementary material (see Supplementary Table 1 ) and are also made available through the Global Biodiversity Information Facility (GBIF; http://www. gbif.org/) and Ocean Biogeographic Information Systems (OBIS; http://iobis.org/) databases via the SCAR Antarctic Biodiversity Portal (biodiversity.aq), accessible through the following doi: 10 . 15468/t223v4 (Drennan et al., 2020).

\section{RESULTS}

\section{Sample Sites and SUCS Imagery}

Four Shallow Underwater Camera System (SUCS) stations corresponded closely with the following AGT sample sites: Duse Bay 200 m, Duse Bay 500 m, PGC Mid 850 m, and PGC South $800 \mathrm{~m}$ (see Figure 1).

Duse Bay (Figure 2A), a sheltered bay located in the northwestern portion of the PGC, is influenced by several local glacier drainage basins (Ferrigno et al., 2006; Scambos et al., 2014); SUCS imagery at both $200 \mathrm{~m}$ (Figures 2B,C) and $500 \mathrm{~m}$ (Figures 2D,E). Duse Bay sites revealed substrate characterized by mud and soft sediments, though with the presence of coarser sediments and very small dropstones or gravel at the $200 \mathrm{~m}$ site. Additional SUCS deployments at $300 \mathrm{~m}$ and $400 \mathrm{~m}$ (not shown) show similar soft muddy substrates to the $500 \mathrm{~m}$ site. While SUCS imagery was not available for the deepest site at this locality, Duse Bay $1000 \mathrm{~m}$, high abundances of burrowing subsurface deposit feeding polychetes in the families Sternaspidae and Maldanidae (see sections "Sample Overview," "Comparison of Sampling Sites") suggest that the substrate here similarly includes soft sediments.

Though also fed by a number of small outlet glaciers (Ferrigno et al., 2006; Scambos et al., 2014), the Prince Gustav Channel 


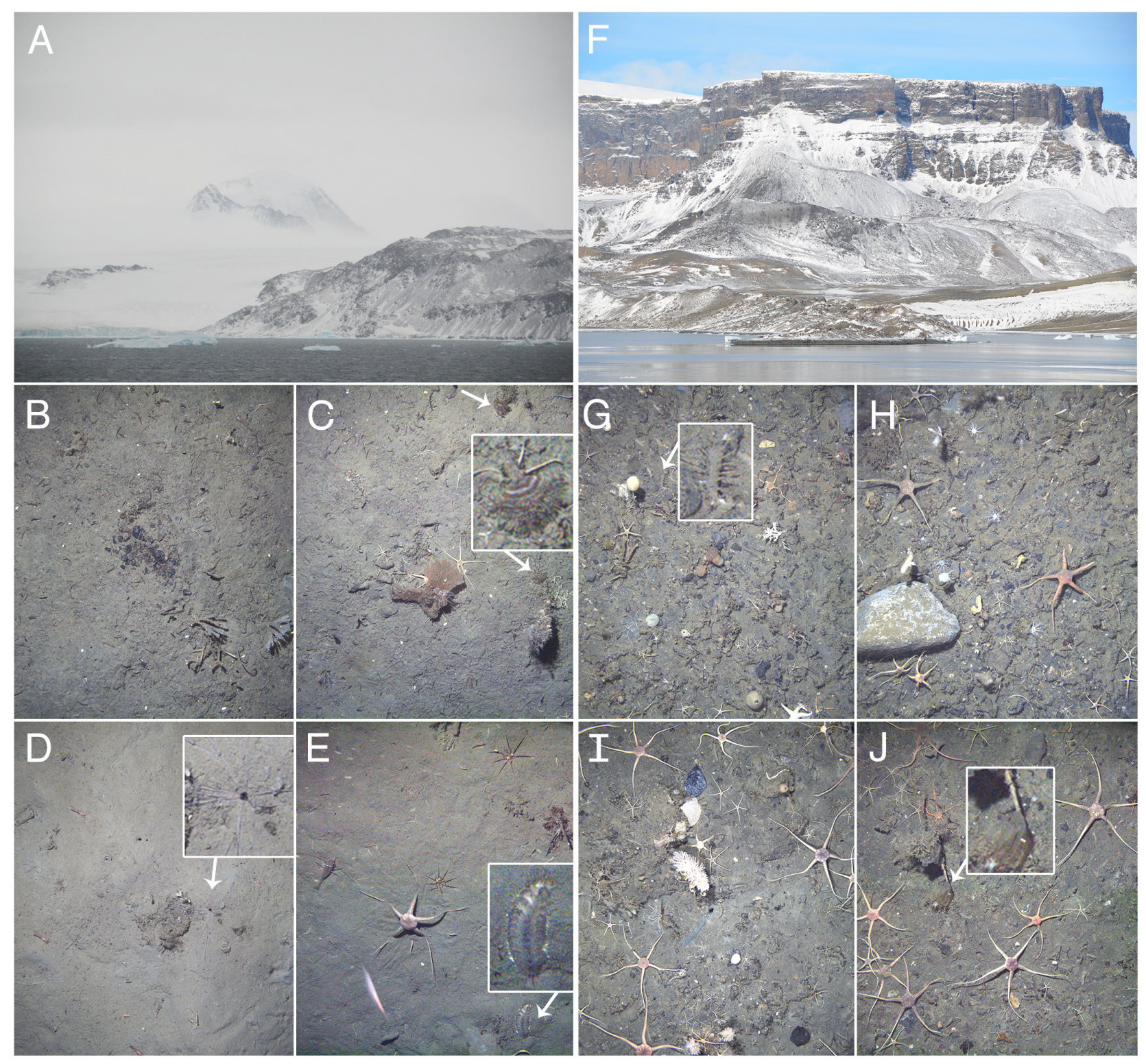

FIGURE 2 | Overview of sites within the Prince Gustav Channel (PGC) including Shallow-water camera system (SUCS) imagery of localities corresponding to AGT sampling sites. (A-E) Duse bay sites, (F-J) PGC sites. SUCS imagery for deepest sites (Duse Bay $1000 \mathrm{~m}$ and PGC South $1200 \mathrm{~m}$ ) was not available due to depth limitations. (A) Above water image of Duse Bay (image credit Angelika Brandt); (B) SUCS event no. 15, Duse Bay $200 \mathrm{~m}$ site; (C) SUCS event no. 15, Duse Bay $200 \mathrm{~m}$ site, with detail of sabellidae polychete; (D) SUCS event no. 11, Duse Bay $500 \mathrm{~m}$ site, with detail of terebellid polychete; (E) SUCS event no. 11, Duse Bay $500 \mathrm{~m}$ site, with detail of polynoid polychete, possibly Austrolaenilla antarctica (see Figure 4D); (F) Above water image of the Prince Gustav Channel (image credit Angelika Brandt); (G) SUCS event no. 45, PGC Mid 850 m site, with detail of flabelligerid polychete, possibly Flabegraviera mundata (see Figure 3B); (H) SUCS event no. 45, PGC Mid 850 m site; (I) SUCS event no. 22, PGC South 800 m site; (J) SUCS event no. 22, PGC South 800 m site, with detail of sabellid polychete.

proper (Figure 2F) is more open than Duse Bay sites, with the narrow, steep-sided nature of channel allowing for a more energetic setting with high current speeds and tidal influence (e.g., Camerlenghi et al., 2001). SUCS imagery from the PGC Mid $850 \mathrm{~m}$ site (Figures 2G,H) revealed substrate dominated by gravel and small stones covered with a thin sediment, and with a number of small dropstones present. Imagery from PGC South $800 \mathrm{~m}$ site (Figures 2I,J) revealed compacted mud and sediment with coarse gravel, and the presence of both small and large dropstones. SUCS imagery from the deepest PGC site, PGC South $1200 \mathrm{~m}$, was similarly unavailable, however an abundance of large surface deposit feeders in the family Flabelligeridae (see section "Comparison of Sampling Sites") suggest that some input of food-bearing sediment is occurring here, though with a notable absence of burrowing taxa.

A number of polychetes were visible in situ in SUCS imagery (Figures 2C,D,E,G,J) including several taxa that possibly correspond with morphospecies collected in AGT samples, such 
as the flabelligerid Flabegraviera mundata (Figures 2G, 3B) and the polynoid Austrolaenilla antarctica (Figures 2E, 4D).

\section{Sample Overview}

In total, approximately 598 individual annelid specimens in roughly 57 morphospecies and at least 25 families were collected across all six AGT deployments (Tables 1-3 and Supplementary Table 1). The preservation quality of the collected specimens was excellent, with many individuals recovered in full without fragmentation, and delicate features such as cirri and elytra often remaining intact (Figures 3, 4). Of the morphospecies, 22 were identified to named species, while five were designated as "cf." and the remaining as morphospecies only (Table 3 ), due to a lack of appropriate taxonomic references and/or poor specimen condition. Morphospecies identified in this study will be subject to future molecular taxonomic and connectivity studies, which may change taxon assignments, for example through the use of genetic data as an error check for morphological assignments (e.g., Neal et al., 2018), and through the discovery of new taxa and cryptic diversity (e.g., Brasier et al., 2016).

The two most abundant species (Table 3 ) were the sternaspid Sternaspis sendalli (Figure 3H) with 176 individuals, and the maldanid Maldane sarsi (Figure 3D) with 121 individuals. If these two species are excluded from the total specimen count, the whole site ratio of individuals to morphospecies is reduced markedly to 301 individuals in 55 morphospecies. Notably, the majority of both of these species were found at a single site, Duse Bay $1000 \mathrm{~m}$ (Table 3).The most diverse group were scale worms in the family Polynoidae, with 10-12 morphospecies recorded (Table 3 and Figures 3I, 4), though with the majority, both in terms of richness and abundance, also found at a single site (Table 2). One polynoid individual (Figure 4I) was identified as a representative of the near-exclusively deep-sea subfamily Macellicephalinae (Neal et al., 2012).

Almost all specimens collected were considered benthic with only one individual recovered from a pelagic family, Tomopteridae. One specimen from the parasitic/commensal family Myzostomidae was recovered, though without an obvious host. Several examples of commensalism were also observed, including two individuals of the Polynoid Polyeunoa laevis, a known alcyonacean coral associate (Barnich et al., 2012), found living within coral branches (Figure 3I); individuals from the families Syllidae and Polynoidae were also found living within glass sponges (e.g., Figure 4A). The majority of specimens exceeded $1 \mathrm{~cm}$ in length, however individual animals ranged in size from several millimeters in families such as Cirratulidae, Dorvilleidae, and Ophelidae to between 15 and $18 \mathrm{~cm}$ long in families such as Maldanidae, Nephtyidae, and Terebellidae.

\section{Comparison of Sampling Sites}

As the size of the sampled area cannot be accurately determined, trawled sampling gear such as the Agassiz trawl are semiquantitative in nature (Eleftheriou and Holme, 1984), and thus, reliable quantitative assessments and comparisons of abundance and diversity between sites within this study is not possible. However, trawls are efficient at sampling large areas and are useful in preliminary studies in terms of providing a broad qualitative overview of the distribution and structure of communities (Arnaud et al., 1998).

Each of the six sample sites varied in terms of abundance, morphospecies richness, Shannon-Wiener diversity, Pielou's evenness, and familial composition (Tables 1-3 and Figure 5). Sites further varied in terms of the dominant functional group present, and the overall size classes of component specimens (Figure 6). Duse Bay sites in general had high proportions of burrowing specimens (Figure 6) with representatives of burrowing families such as Cirratulidae, Lumbrineridae (e.g., Figure 4C), and Maldanidae (e.g., Figure 4D) present at each site, though with overall taxonomic composition varying between individual sites (Figure 5). Sites in the channel proper varied somewhat more in terms of dominant taxa and functional groups (Figures 5 and 6).

Duse Bay $200 \mathrm{~m}$, the shallowest site sampled, displayed moderate abundance and richness, relative to other sites, and possessed the highest proportion of suspension feeders with 25 individuals from the tube building family Sabellidae in two morphospecies. However, the majority of these consisted of 14 individuals of the morphospecies Sabellidae sp. NHM_272 (Figure 3G) that formed a single cluster of tubes on the end of a large empty tube, possibly belonging to the terebellid Pista mirabilis (Figure 3K) of which there were three individuals also present in the sample, up to $15 \mathrm{~cm}$ in length.

Duse Bay $500 \mathrm{~m}$ displayed relatively high abundances and the highest morphospecies and familial richness by considerable margin, with 32 morphospecies in 19 families across 99 individuals. The sample was dominated by burrowing taxa (Figure 6), with Maldanidae representing the most abundant family (36 individuals across three morphospecies), comprising mainly of Maldane sarsi (33 individuals) (Figure 4D). In addition to families not well represented at other sites such as Cirratulidae, many families such as Dorvilleidae, Hesionidae, Opheliidae, Orbiniidae, Paraonidae, and Scalibregmatidae were found exclusively at this site (Table 2). These families primarily included small, macrofaunal sized individuals approximately $1 \mathrm{~cm}$ in length or shorter. In contrast, the sample also included several notably large specimens, including an individual of the terebellid Pista mirabilis (Figure 3K) exceeding $18 \mathrm{~cm}$ in length, an anterior fragment of the large nephtyid Aglaophamus trissophyllus (Figure 3E) exceeding $15 \mathrm{~cm}$ in length, and six individuals of the large syllid Trypanosyllis gigantea (Figure 3J) $(2.5-10 \mathrm{~cm}$ long) found living within a glass sponge.

Duse Bay $1000 \mathrm{~m}$ presented the highest abundances observed across all sites with 260 individuals, though as discussed in section "Sample Overview," this sample was primarily made up of two species, Sternaspis sendalli and Maldane sarsi, with richness otherwise relatively low with 10 morphospecies. While M. sarsi is moderate in size $(\sim 2 \mathrm{~mm}$ wide though reaching lengths of up to $12 \mathrm{~cm}$ in the largest specimens), $S$. sendalli is small with most specimens not exceeding $1 \mathrm{~cm}$ in length - this site therefore displayed the highest proportion of small macrofaunal sized taxa (Figure 6). While M. sarsi was found at relatively high abundances in all but two sites (PGC Mid $850 \mathrm{~m}$ and PGC South 
TABLE 2 | Number of individuals and morphospecies per polychete family (or higher taxonomic rank in the case of oligochaeta) sampled during cruise JR17003a.

\begin{tabular}{|c|c|c|c|c|c|c|c|c|c|c|c|c|c|c|c|}
\hline \multirow{3}{*}{$\begin{array}{l}\text { Family } \\
\text { (or higher) }\end{array}$} & \multirow{3}{*}{$\begin{array}{l}\text { Functional } \\
\text { category }\end{array}$} & & & \multicolumn{12}{|c|}{ Sites } \\
\hline & & \multicolumn{2}{|c|}{ Total Site } & \multicolumn{2}{|c|}{ Duse Bay 200 m } & \multicolumn{2}{|c|}{ Duse Bay 500 m } & \multicolumn{2}{|c|}{ Duse Bay 1000 m } & \multicolumn{2}{|c|}{ PGC Mid 850 m } & \multicolumn{2}{|c|}{ PGC South 800 m } & \multicolumn{2}{|c|}{ PGC South 1200 m } \\
\hline & & No. ind. & No. sp. & No. ind. & No. sp. & No. ind. & No. sp. & No. ind. & No. sp. & No. ind. & No. sp. & No. ind. & No. sp. & No. ind. & No. sp. \\
\hline Ampharetidae & tbsdf & 5 & 1 & 2 & 1 & 2 & 1 & - & - & - & - & 1 & 1 & - & - \\
\hline Cirratulidae & $\mathrm{b}$ & 10 & 4 & 2 & 1 & 7 & 4 & 1 & 1 & - & - & - & - & - & - \\
\hline Dorvilleidae & msom & 5 & 1 & - & - & 5 & 1 & - & - & - & - & - & - & - & - \\
\hline Flabelligeridae & msdf & 27 & 2 & - & - & - & - & - & - & 10 & 2 & - & - & 17 & 1 \\
\hline Hesionidae & msom & 1 & 1 & - & - & 1 & 1 & - & - & - & - & - & - & - & - \\
\hline Lumbrineridae & $b$ & 12 & 2 & 1 & 1 & 6 & 2 & 4 & 1 & - & - & 1 & 1 & - & - \\
\hline Maldanidae & $b$ & 133 & 4 & 8 & 1 & 36 & 3 & 68 & 2 & - & - & 21 & 3 & - & - \\
\hline Myzostomidae & pa & 1 & 1 & - & - & - & - & - & - & - & - & 1 & 1 & - & - \\
\hline Nephtyidae & msom & 17 & 2 & - & - & 4 & 2 & 6 & 1 & 6 & 1 & - & - & 1 & 1 \\
\hline Oligochaeta & $b$ & 3 & 2 & - & - & 3 & 2 & - & - & - & - & - & - & - & - \\
\hline Opheliidae & $b$ & 6 & 2 & - & - & 6 & 2 & - & - & - & - & - & - & - & - \\
\hline Orbiniidae & $b$ & 4 & 1 & - & - & 4 & 1 & - & - & - & - & - & - & - & - \\
\hline Oweniidae & tbsdf & 16 & 1 & - & - & 1 & 1 & - & - & 15 & 1 & - & - & - & - \\
\hline Paraonidae & $\mathrm{b}$ & 1 & 1 & - & - & 1 & 1 & - & - & - & - & - & - & - & - \\
\hline Phyllodocidae & msom & 5 & 3 & 1 & 1 & - & - & 1 & 1 & 3 & 3 & - & - & - & - \\
\hline Polynoidae & msom & 105 & 12 & 2 & 2 & 3 & 3 & 6 & 2 & 82 & 10 & 6 & 5 & 6 & 2 \\
\hline Sabellidae & tbsf & 29 & 2 & 25 & 2 & 2 & 1 & - & - & 1 & 1 & 1 & 1 & - & - \\
\hline Scalibregmatidae & $b$ & 1 & 1 & - & - & 1 & 1 & - & - & - & - & - & - & - & - \\
\hline Serpulidae & tbsf & 1 & 1 & - & - & 1 & 1 & - & - & - & - & - & - & - & - \\
\hline Sternaspidae & $\mathrm{b}$ & 176 & 1 & 2 & 1 & - & - & 173 & 1 & - & - & 1 & 1 & - & - \\
\hline Syllidae & msom & 19 & 4 & - & - & 7 & 2 & - & - & 7 & 2 & 5 & 2 & - & - \\
\hline Terebellidae & tbsdf & 11 & 5 & 4 & 2 & 2 & 2 & 1 & 1 & 2 & 1 & 2 & 2 & - & - \\
\hline Tomopteridae & pe & 1 & 1 & - & - & - & - & - & - & - & - & 1 & 1 & - & - \\
\hline Travisiidae & b & 1 & 1 & - & - & - & - & - & - & - & - & 1 & 1 & - & - \\
\hline Trichobranchidae & tbsdf & 8 & 1 & 1 & 1 & 7 & 1 & - & - & - & - & - & - & - & - \\
\hline Total & & 598 & 57 & 48 & 13 & 99 & 32 & 260 & 10 & 126 & 21 & 41 & 19 & 24 & 4 \\
\hline
\end{tabular}


TABLE 3 | List of morphospecies identified from Agassiz Trawl samples collected on cruise JR17003a, with individual counts for each site provided.

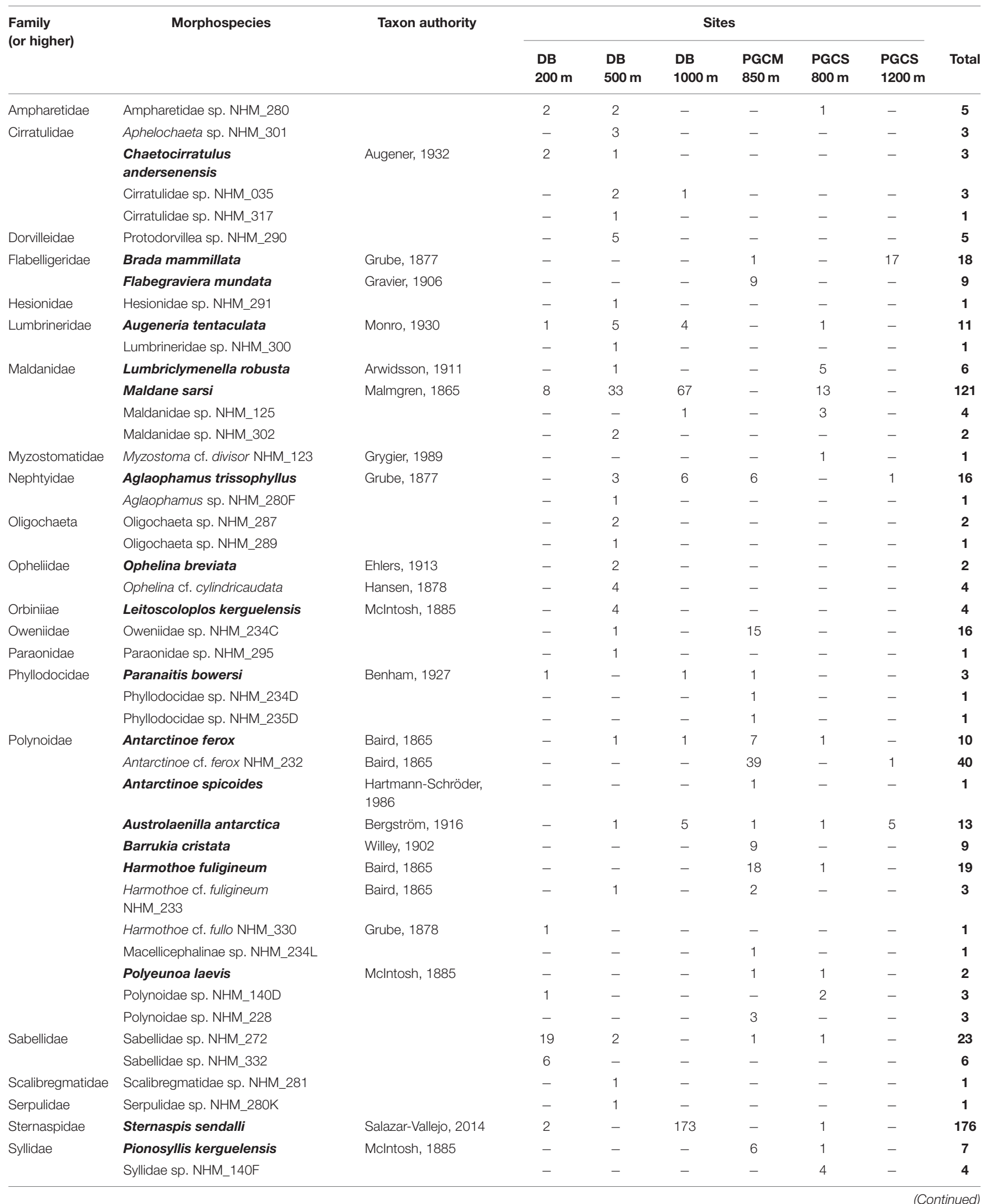


TABLE 3 | Continued

\begin{tabular}{|c|c|c|c|c|c|c|c|c|c|}
\hline \multirow{3}{*}{$\begin{array}{l}\text { Family } \\
\text { (or higher) }\end{array}$} & \multirow[t]{3}{*}{ Morphospecies } & \multirow[t]{3}{*}{ Taxon authority } & \multicolumn{6}{|c|}{ Sites } & \multirow{3}{*}{ Total } \\
\hline & & & DB & DB & DB & PGCM & PGCS & PGCS & \\
\hline & & & $200 \mathrm{~m}$ & $500 \mathrm{~m}$ & $1000 \mathrm{~m}$ & $850 \mathrm{~m}$ & $800 \mathrm{~m}$ & $1200 \mathrm{~m}$ & \\
\hline & Syllidae sp. NHM_285 & & - & 1 & - & - & - & - & 1 \\
\hline & Trypanosyllis gigantea & Mclntosh, 1885 & - & 6 & - & 1 & - & - & 7 \\
\hline \multirow[t]{5}{*}{ Terebellidae } & Leaena collaris & Hessle, 1917 & - & 1 & - & - & - & - & 1 \\
\hline & Pista mirabilis & Mclntosh, 1885 & 3 & 1 & - & - & - & - & 4 \\
\hline & Terebellidae sp NHM_142 & & - & - & 1 & - & 1 & - & 2 \\
\hline & Terebellidae sp NHM_234P & & - & - & - & 2 & 1 & - & 3 \\
\hline & Terebellidae sp NHM_337 & & 1 & - & - & - & - & - & 1 \\
\hline Tomopteridae & Tomopteris sp NHM_131 & & - & - & - & - & 1 & - & 1 \\
\hline Travisiidae & Travisia kerguelensis & Mclntosh, 1885 & - & - & - & - & 1 & - & 1 \\
\hline Trichobranchidae & Trichobranchidae sp. 280M & & 1 & 7 & - & - & - & - & 8 \\
\hline
\end{tabular}

Taxa identified to named species are highlighted in bold. DB Duse Bay; PGC Prince Gustav Channel; M Mid; S South.

$800 \mathrm{~m}$ ), notably only a handful of $S$. sendalli were found at other sites despite being the most abundant species overall. Both species are burrowing deposit feeders, and Duse Bay $1000 \mathrm{~m}$ further presented the highest proportion of burrowing taxa across all sites (Figure 6). The remaining sample was primarily composed of medium to large sized motile scavenger/predator taxa including the large nephtyid Aglaophamus trissophyllus, the phyllodocid Paranaitis bowersi (Figure 3F) and the polynoids Antarctinoe ferox and Austrolaenilla antarctica (Figures 4A,D).

Sites in the channel proper were more variable. PGC Mid $850 \mathrm{~m}$ presented relatively high diversity and both the second highest abundance and richness of any site, with 126 individuals in 21 morphospecies, and is notable in that no burrowing taxa were present (Figure 6). While representatives of the family Polynoidae were present in small to moderate numbers across every site, PGC Mid $850 \mathrm{~m}$ is further notable in terms of a striking abundance and richness of polynoids with 82 individuals in at least 10 morphospecies (Figures 3I, 4A-I), ranging in size from $2 \mathrm{~cm}$ to $>6 \mathrm{~cm}$. Other motile scavenger/predator taxa in Nephtyidae, Phyllodocidae, and Syllidae were also moderately abundant. Ten individuals in the motile surface deposit feeding family Flabelligeridae were also present at the site, including nine individuals of the species Flabegraviera mundata (Figure 3B), possibly visible in situ in SUCS imagery of this site (Figure 2G). Additionally, 15 individuals of an unidentified oweniid morphospecies, Oweniidae sp. NHM_234C, were present at this site, with the family being rare or absent entirely from other sites.

PGC South $800 \mathrm{~m}$ displayed relatively low abundance but moderate richness, with 41 individuals in 19 morphospecies, and was the only non-Duse Bay site with burrowing taxa, primarily comprised of the family Maldanidae (Figures 5, 6) but also including representatives in families Lumbrineridae, Sternaspis and Travisiidae. The remaining taxa were mainly composed of motile surface scavenger/predators in families Polynoidae and Syllidae.

PGC South $1200 \mathrm{~m}$ was the deepest site sampled, with a maximum depth of $1270 \mathrm{~m}$. The site displayed both the lowest abundance and richness of any site, with 24 individuals in four morphospecies, dominated by 17 individuals of the large $(4-7 \mathrm{~cm})$ flabelligerid Brada mammillata (Figure 3A), in addition to two species of polynoid (Austrolaenilla antarctica and Antarctinoe cf. ferox sp. NHM_232) and the nephtyid Aglaophamus trissophyllus. The site therefore was entirely composed of motile surface dwelling taxa, and further displayed the greatest proportion of large, megafaunal sized animals exceeding $5 \mathrm{~cm}$ (Figure 6).

Shannon-Wiener diversity indexes were lowest in the deepest stations, Duse Bay $1000 \mathrm{~m}$ and PGC South $1200 \mathrm{~m}\left(\mathrm{H}^{\prime}=0.95\right.$ and 0.84 , respectively) and highest at Duse Bay $500 \mathrm{~m}\left(\mathrm{H}^{\prime}=2.75\right)$. Values for Pielou's Evenness were also lowest for the two deepest stations ( $J^{\prime}=0.41$ and 0.60 , respectively), ranging between $\mathrm{J}^{\prime}=0.76$ and $\mathrm{J}^{\prime}=0.83$ at the remaining sites.

\section{DISCUSSION}

\section{General Overview}

This study provides a first insight into the benthic annelid fauna of the Prince Gustav Channel, revealing locally variable communities in terms of abundance, richness, and both taxonomic and functional composition.

Fine scale habitat heterogeneity, for example in terms of substrate type and composition and the presence or absence of dropstones, can account for much of the variation observed in faunal composition in several previous studies of Antarctic shelf benthos, including investigations of the East Antarctic Shelf (Post et al., 2017), the Ross Sea (Cummings et al., 2006), King George Island (Quartino et al., 2001), and the South Orkney Islands (Brasier et al., 2018). In the present study, SUCS imagery at Duse Bay sites revealed substrate characterized by mud and soft sediments, reflected in high abundances of burrowing taxa at these sites, primarily subsurface deposit feeding families such as Maldanidae and Sternaspidae. Though SUCS imagery was not available for the deepest site (Duse Bay $1000 \mathrm{~m}$ ), high abundances of these taxa suggest substrate also composed of soft sediments. Previous studies of Antarctic shelf annelids have found high abundances of subsurface deposit feeding taxa to 

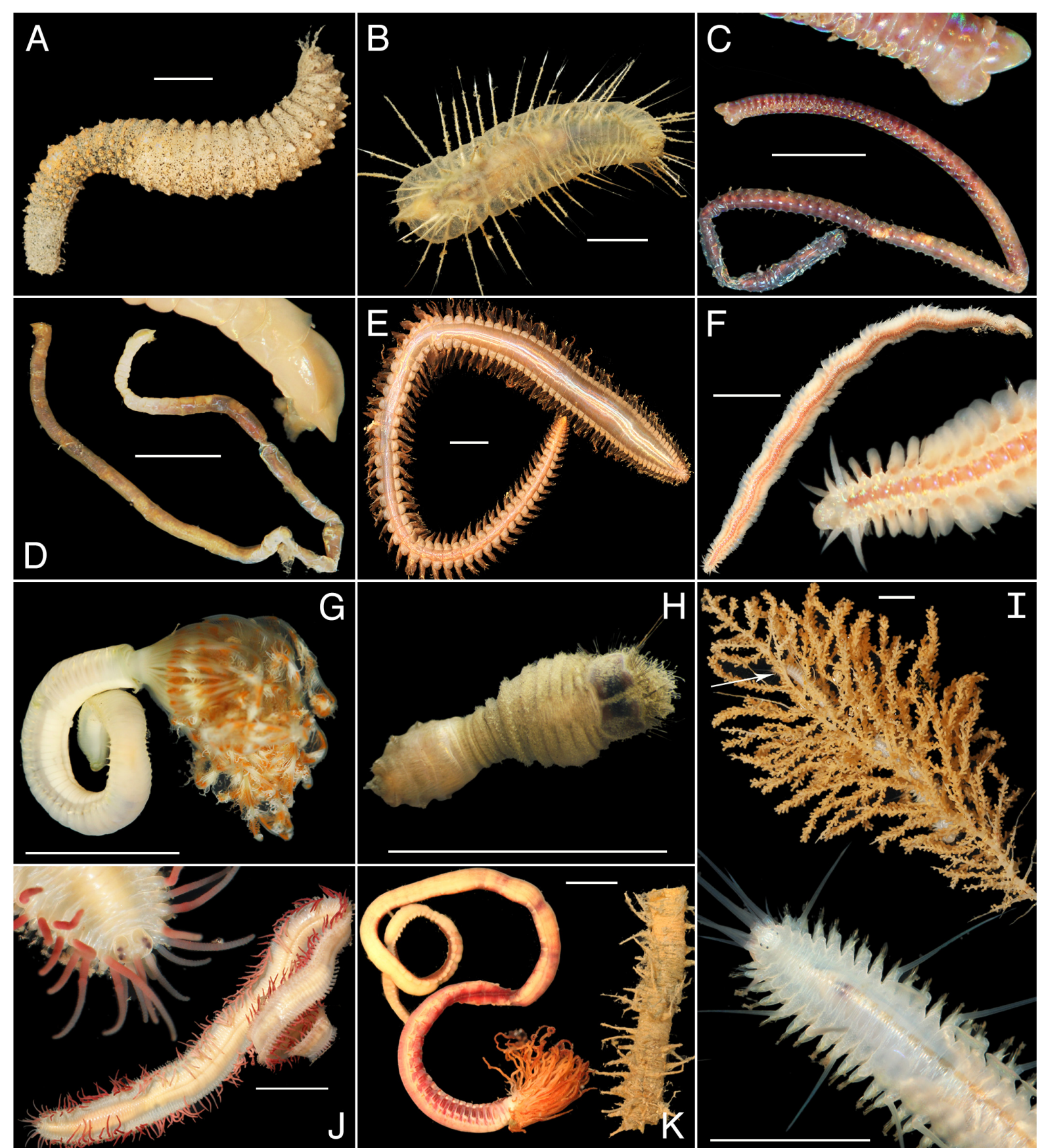

FIGURE 3 | Live specimen imagery taken on board the expedition JR17003a of several annelid species or morphospecies across a range of families collected by AGT trawls. (A) Brada mammillata (Flabelligeridae); (B) Flabegraviera mundata (Flabelligeridae); (C) Augeneria tentaculata (Lumbrineridae), whole specimen (bottom), with detail of prostomium (top); (D) Maldane sarsi (Maldanidae), whole specimen (bottom) with detail of prostomium (top); (E) Aglaophamus trissophyllus (Nephtyidae), (F) Paranaitis bowersi (Phyllodocidae), whole specimen (top) with detail of anterior (bottom); (G) Sabellidae sp. NHM_272; (H) Sternaspis sendalli (Sternaspidae); (I) Polyeunoa laevis (Polynoidae), whole specimen living within branches of coral (top) and detail of specimen anterior (bottom); (J) Trypanosyllis gigantea (Syllidae), whole specimen (bottom) with detail of anterior (top); (K) Pista mirabilis (Terebellidae) whole specimen (left) alongside portion of tube (right). All scale bars $=1 \mathrm{~cm}$.

correspond with enhanced productivity and food availability in sediments (e.g., Neal et al., 2011). Duse Bay is a sheltered embayment influenced by a number of local outlet glaciers (Ferrigno et al., 2006; Scambos et al., 2014); in addition to the collapse of floating ice shelves, maritime glaciers along the Antarctic Peninsula have also experienced dramatic retreat in recent decades (Cook et al., 2005), with freshening and sedimentation events becoming more frequent due to increased 


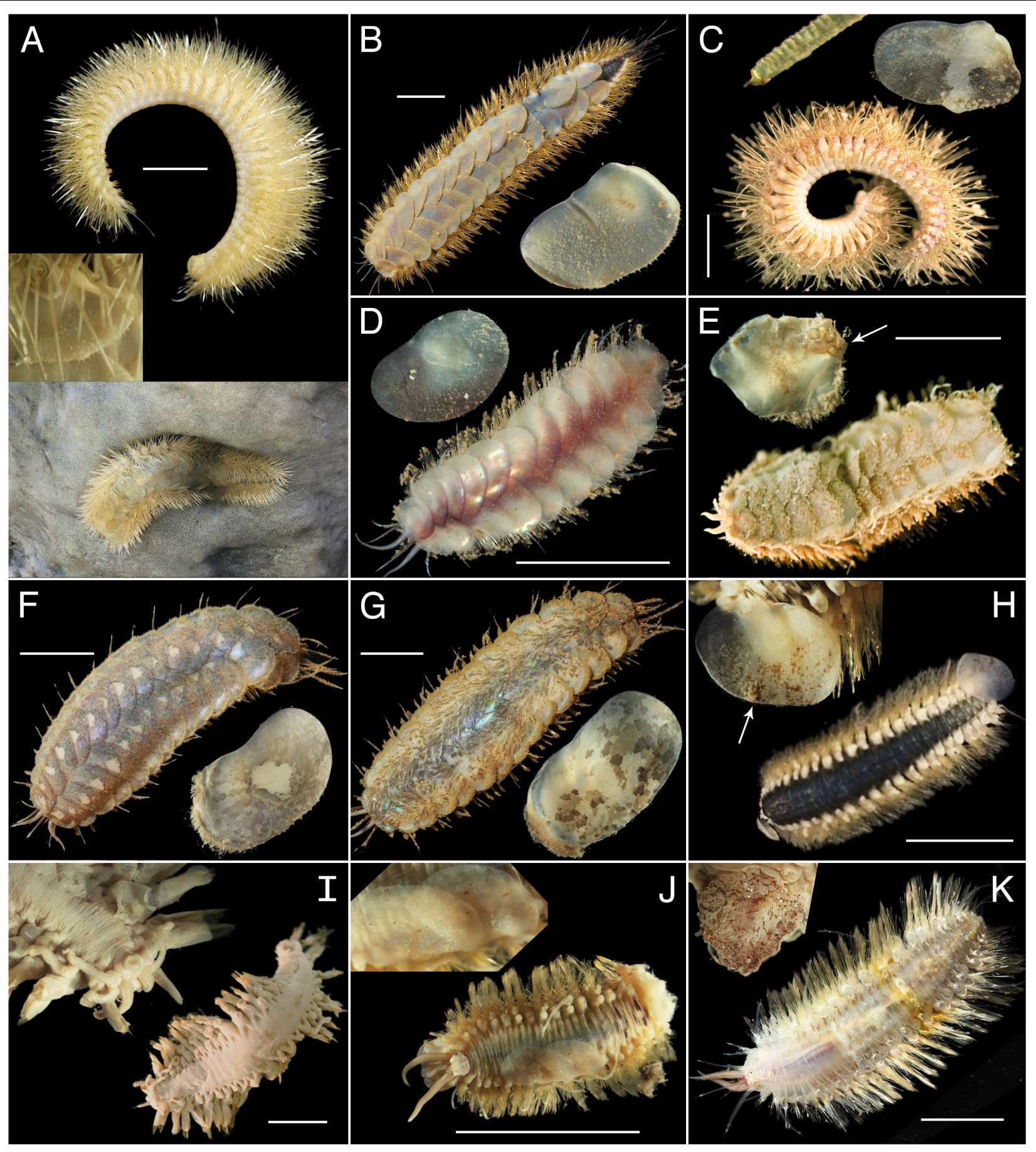

FIGURE 4 | Specimen imagery highlighting morphospecies diversity of the family Polynoidae collected JR17003a expedition. See also Figure 3I. (A) Antarctinoe ferox live image, lateral view (top), detail of elytra on preserved specimen (middle) and live, in situ image of specimen sitting in glass sponge; (B) Antarctinoe cf. ferox NHM_232, live image, with detail of midbody elytron (preserved); (C) Antarctinoe spicoides, preserved specimen, lateral view (bottom), detail of long notochaetal spine with pin tip (top left) and detail of midbody elytron (right); (D) Austrolaenilla antarctica live image, with detail of midbody elytron (preserved); (E) Barrukia cristata, preserved specimen, with detail of elytron with arrow highlighting large macrotubercles; F Harmothoe cf. fuligineum NHM_233, live image, with detail of elytron (preserved); (G) Harmothoe fuligineum, with detail of elytron; (H) Harmothoe cf. fullo NHM_330, preserved specimen, with detail of elytron, arrow highlighting mound on posterior margin; (I) Macellicephalinae sp. NHM_234L, preserved specimen, with detail of anterior (top left); (J) Polynoidae sp. NHM_140, preserved specimen, with detail of elytra; (K) Polynoidae sp. NHM_228, live image, with detail of elytron (preserved specimen, different individual to one shown in live image). All scale bars $=1 \mathrm{~cm}$ 


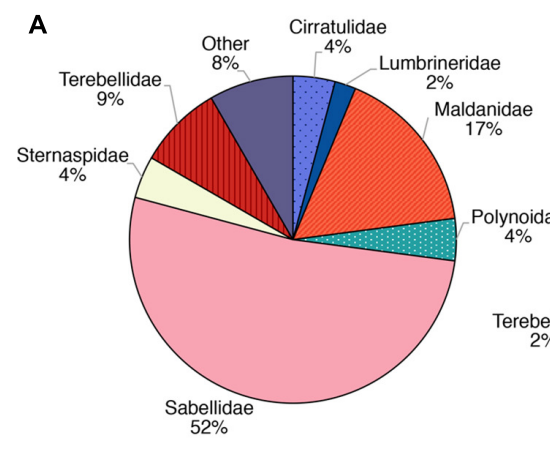

Duse Bay $200 \mathrm{~m}(n=48)$
B

B

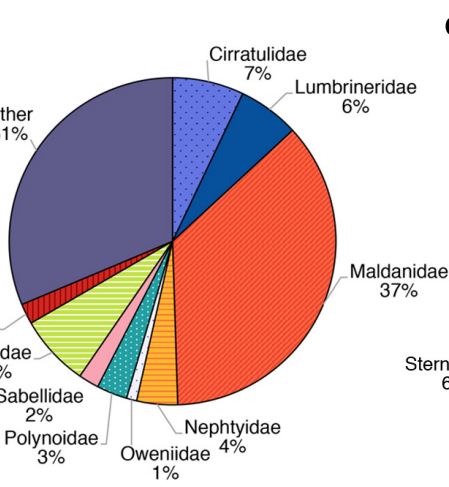

E
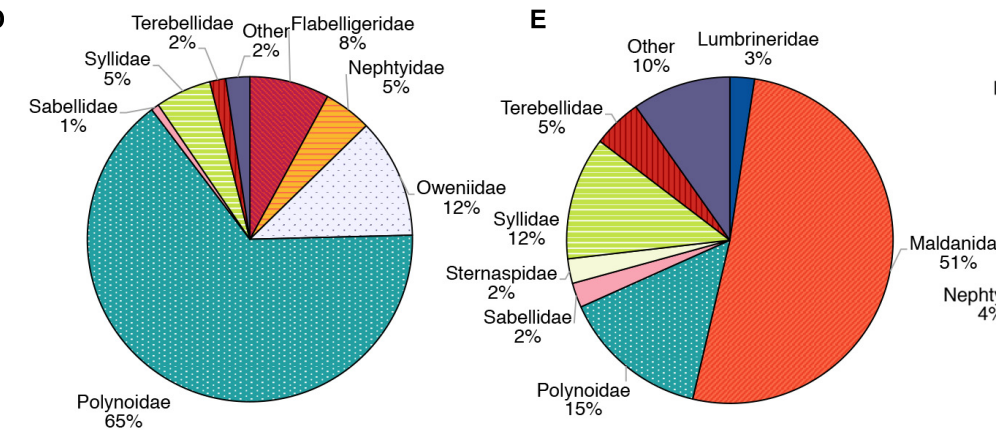

$\mathbf{F}$
Duse Bay $1000 \mathrm{~m}(n=260)$

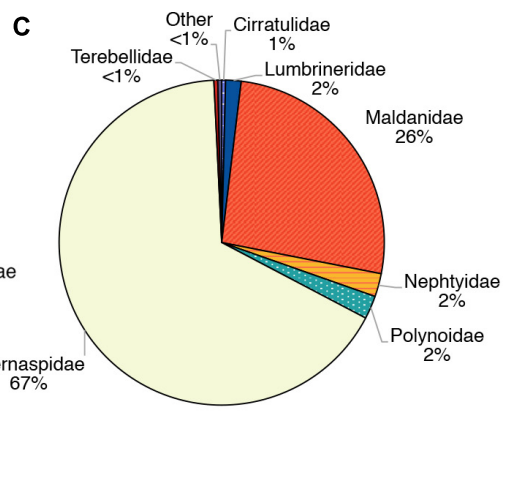

PGC Mid 850 m $(n=126)$
PGC South $800 \mathrm{~m}(n=41)$

$\square$ Flabelligeridae
$\square$ Nephtyidae
$\square$ Sabellidae
$\square$ Terebellidae

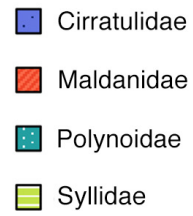

FIGURE 5 | Proportions of total specimen abundance by annelid family for each Agassiz Trawl sample site. (A) Duse Bay 200 m (B) Duse Bay 500 m (C) Duse Bay 1000 m (D) PGC Mid 850 m (E) PGC South 800 m (F) PGC South 1200 m. Families that had less than ten individuals across all sites (14 out of a total of 25 families) were combined into a single category, "other."

influxes of glacial meltwater and sediment runoff associated with glacial retreat (Smale and Barnes, 2008). These disturbances can affect adjacent benthic communities in a number of ways. For example, the presence of surface meltwater has been associated with nearshore phytoplankton blooms and increased primary productivity (Dierssen et al., 2002), and increased sedimentation with shifts in benthic community structures (Sahade et al., 2015), favoring soft substrate adapted taxa. Glacial input can also locally increase habitat complexity through the deposition of dropstones - land derived rock frozen into glacial ice that enter the sea via icebergs, which deposit the stones as they melt, providing hard substrata where they land (Smale and Barnes, 2008). Both large and small dropstones were visible throughout the channel where SUCS imagery was available, though in Duse Bay these were mainly restricted to the shallowest site (Duse Bay $200 \mathrm{~m}$ ).
Glaciers that previously fed into the Prince Gustav Ice Shelf experienced accelerated ice loss and discharge into PGC embayments following the collapse of the ice shelf and its buttressing effect in 1995, though with a significant reduction in losses since 2013 (Rott et al., 2014, 2018). In addition to glacial input into the channel, the depth and north-south continuity of the PGC may further facilitate the flow of fine grained sediment and organic matter through the channel from adjacent shelf areas and more productive, seasonally open water, even during periods when the channel was covered by a floating ice shelf, which is possibly indicated by a measurable drape of diatom bearing sediment in the deepest parts of the channel, much thicker than for other glacial troughs in the region (Pudsey et al., 2001). This may have relevance to benthic communities in the channel today, as while the collapse of ice shelves exposed open water leading to massive increases in primary production in the 

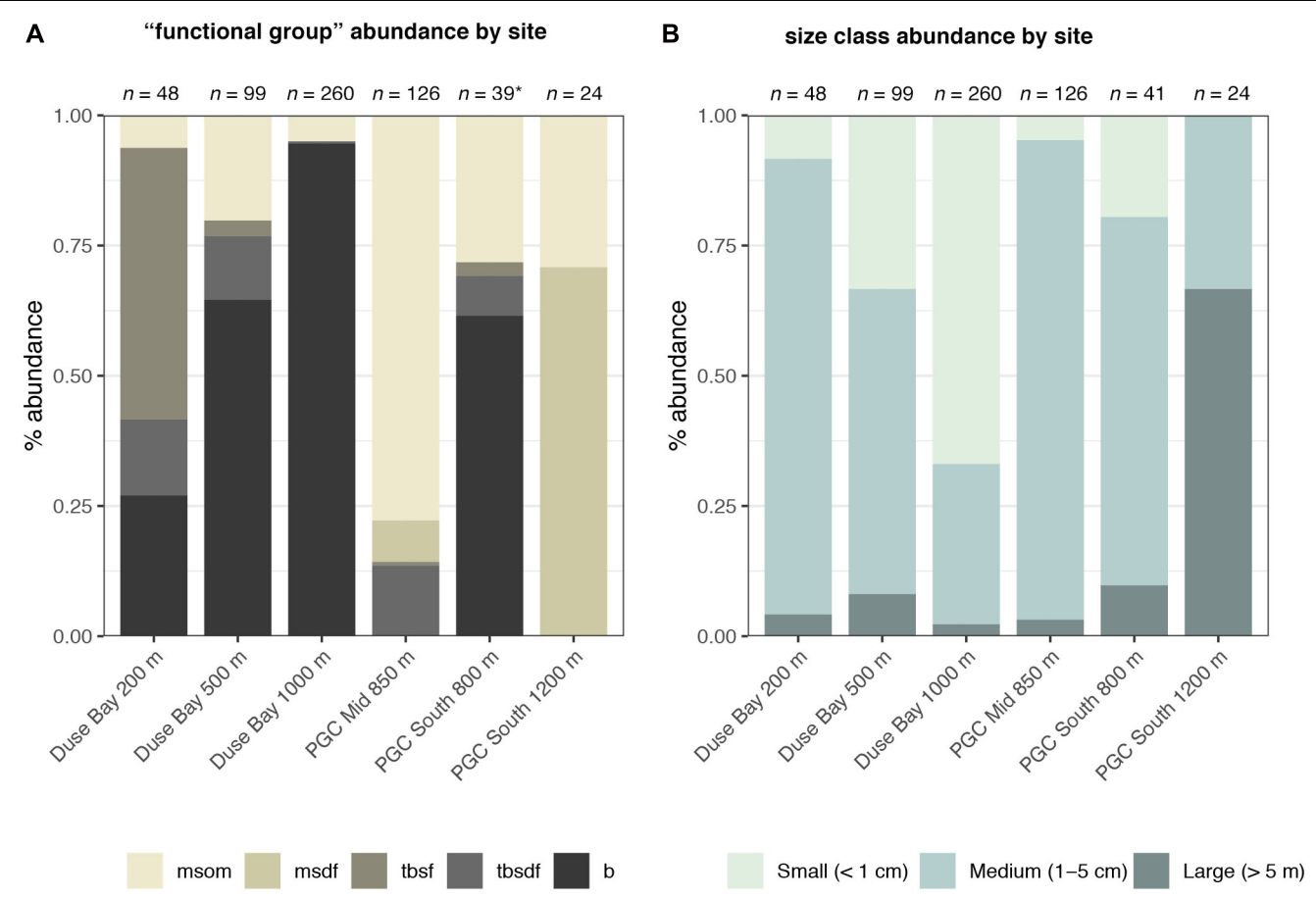

FIGURE 6 | Composition of annelid (A) "functional groups" and (B) size classes in terms of percentage abundance of individuals across all sampled AGT stations. (A) Polychete families were separated into broad functional categories based on shared functional traits such as life habit, motility and feeding behavior as follows: msom (motile surface-dwelling omnivorous); msdf (motile surface-dwelling deposit-feeding); tbsdf (tube-building surface deposit-feeding); tbsf (tube-building suspension-feeding); b (burrowing). See Table 2 for list of functional groups by family. ${ }^{*}$ Singleton specimens representing parasitic (pa) and pelagic (pe) functional groups (see Table 2) were excluded from PGC South $800 \mathrm{~m}$. (B) Specimens were organized into general size classes as follows: small (less than $1 \mathrm{~cm}$ in length); medium (between 1-5 cm in length, or for long, slender taxa, less than $0.5 \mathrm{~cm}$ in width); large (exceeding $5 \mathrm{~cm}$ in length and $0.5 \mathrm{~cm}$ in width).

region (Bertolin and Schloss, 2009), the east coast of the Antarctic Peninsula experiences dense pack ice cover for much of the year, with pack ice in the channel occasionally lasting year round (Pudsey et al., 2006). Cut off from surface primary production, benthic communities beneath floating ice shelves are known to rely on the horizontal advection of food particles from open water as a primary food source (Riddle et al., 2007), with distance from the ice shelf edge a major factor in terms of the abundance, diversity and structure of sub-ice benthic communities (e.g., Riddle et al., 2007; Post et al., 2014).

In this study, SUCS imagery corresponding to sampled channel sites revealed higher proportions of hard substrate relative to Duse Bay sites, though with mud and compacted sediment present at PGC South $800 \mathrm{~m}$ (possibly reflected in an abundance of maldanids) and only a thin sediment drape at PGC Mid $850 \mathrm{~m}$, the latter displaying remarkable abundance and diversity in the motile predator/scavenger family Polynoidae and the complete absence of sub-surface deposit feeding taxa. While SUCS imagery was not possible for the deepest basin of the channel, PGC South $1200 \mathrm{~m}$, previous acoustic investigations have shown that the deeper parts of the channel are filled by a measurable sediment drape (Pudsey et al., 2001). The benthic fauna of this site was distinct from other samples with the lowest richness, abundance, and diversity, entirely dominated by large motile megafauna, primarily in the surface deposit feeding family Flabelligeridae but also including predator/scavenger families
Polynoidae and Nephtyidae. In a comparative study of depth zonation in polychete communities from Scotia and Amundsen seas, deep glacial troughs up to $1500 \mathrm{~m}$ deep in the inner shelf of the glacier-influenced Pine Island Bay in the Amundsen Sea were dominated by motile predator/scavengers such as Polynoidae and Nephtyidae and deposit feeding families (both surface and subsurface) at $500 \mathrm{~m}$ depth horizons; deeper sites were entirely dominated by the former with a complete absence of deposit feeders (Neal et al., 2018). The basins of the PGC are amongst a number of deep glacial troughs that exceed depths of $800 \mathrm{~m}$ in the greater Larsen A area, though are distinct in having a much thicker drape of diatom bearing sediment than other troughs in the region, suggesting that the bathymetry of the channel facilitates the advection of food bearing particles from more productive waters through the channel and to these troughs (Pudsey et al., 2001). This could possibly support deposit feeding communities in the deep basins of the PGC, however comparative samples from other troughs in the region are not available.

In the Amundsen Sea, Antarctic Circumpolar Deep water is known to intrude onto the inner shelf of Pine Island Bay (Thoma et al., 2008), connecting the shelf troughs with deep water and acting as a potential source of the deep-water species found in these troughs (e.g., Kaiser et al., 2009; Riehl and Kaiser, 2012; Linse et al., 2013), including polynoids in the deep sea sub-family Macellicephalinae (Neal et al., 2012, 2018). 
An individual of this subfamily was collected in the present study from PGC Mid $850 \mathrm{~m}$ site. On the continental shelf of the greater Larsen region, glacial troughs running out to the continental shelf break allow for the inflow of Modified Weddell Deep Water, a derivative of Circumpolar Deep Water, onto the shelf and toward the coast and ice shelf fronts (Nicholls et al., 2004), though it is unknown whether this could similarly act as a source of deep sea taxa on the western Weddell shelf without comparative faunistic studies with deep Weddell communities.

Southern Ocean polychetes are typically reported to have wide depth ranges (Schüller, 2011), however this notion is beginning to be challenged, with recent comparative investigations finding depth to be one of the main factors structuring shelf and slope polychete communities (Neal et al., 2018). As the sample size in this study was small and qualitative, and with three sampling depths only achieved at Duse Bay sites, any effects of depth are difficult to discern. In a separate analysis of the 12 SUCS deployments taken throughout the channel on the JR17003a expedition from depths ranging from $200 \mathrm{~m}$ to $850 \mathrm{~m}$, heterogeneity and complexity was found to decrease with depth, with the most complex and heterogeneous sites found at the southern-most sample sites (Almond, 2019).

Without comparable baseline records from the Prince Gustav Channel, either before or directly after ice shelf collapse, any effects of ice loss on the benthos of the channel are similarly difficult to discern. Based on historical records, the maximum northern extent of the Prince Gustav Ice shelf in contemporary terms would have extended to just south of the PGC South $1200 \mathrm{~m}$ sampling site (Cooper, 1997; Ferrigno et al., 2006). Sites in this study therefore would have been just proximal to the ice shelf rather than directly covered by it, however the effects of this are similarly unknown.

\section{Sampling Biases and Comparability}

The Agassiz Trawl is best suited for collecting large epifauna or large infauna at or close to the sediment surface interface, and can be hindered by very rocky substrate, hence why $200 \mathrm{~m}$ and $500 \mathrm{~m}$ trawls in the main channel were not possible due to the influence of boulders. This may explain why the sample site with the largest dropstones, PGC South $800 \mathrm{~m}$, displayed relatively low abundances despite moderately high morphospecies richness. The nature of the trawl further limits the collection of smaller encrusting species, and larger numbers of small infaunal species than otherwise targeted can occasionally be collected when the trawl becomes embedded in soft sediment (Brasier et al., 2018), as likely occurred at Duse Bay $500 \mathrm{~m}$ site, which displayed the highest diversity and highest overall familial and morphospecies richness, largely from small infaunal taxa.

Placing these results in wider comparative terms is difficult due to the above sampling biases and general qualitative nature of the AGT, in addition to the range of sampling devices and different spatial and bathymetric scales used by previous benthic sampling projects. The majority of Antarctic macrobenthic abundance and diversity assessments have been carried out using grabs and corers (Linse et al., 2007), including the only previous biological sampling effort of the Prince Gustav Channel in 2000 (see Blake, 2015), and a number of large-scale assessments of Antarctic polychete diversity (e.g., Hilbig et al., 2006; Neal et al., 2011; Parapar et al., 2011). Coring devices, which are considered more quantitative than dragged gear at the cost of area sampled, may only have a low degree of species overlap with sledged or trawled sampling gear even at the same site (Hilbig, 2004). Several large Antarctic polychete studies have collected samples using an epibenthic sledge (EBS) (e.g., Schüller et al., 2009; Neal et al., 2018), however while the EBS is similarly a dragged sampling gear, it targets a smaller size class of fauna than the Agassiz trawl, again limiting comparability. The standardized use of multiple gear types at any one station is an efficient method of getting a comprehensive impression of the benthic fauna of an area, particularly where seafloor is sparsely colonized (Hilbig, 2004). Core and EBS samples were also taken during the JR17003a expedition and will be incorporated in future taxonomic studies using an integrative taxonomy approach (Glover et al., 2016), whereby morphological assessments are streamlined by molecular barcoding, and will provide a more holistic and comparable account of polychete diversity in the Prince Gustav Channel. However, AGT samples provide a good preliminary overview of the megafaunal and larger macrofaunal communities of the channel.

Antarctic AGT-based sampling efforts that are broadly comparable include the second expedition of the Ecology of the Antarctic Sea Ice Zone (EASIZ) program on board the RV Polarstern in 1998, in which 11 AGT trawls from depths ranging from $230 \mathrm{~m}-2070 \mathrm{~m}$, primarily from the continental shelf and slope of the southeastern Weddell Sea, were sorted to family level (Arntz and Gutt, 1999). If excluding single locally abundant species such as Sternaspis sendalli at Duse Bay $1000 \mathrm{~m}$, then the EASIZ AGT samples are broadly similar to the samples of this study in terms of total annelid abundances and familial richness, ranging from 28-101 individuals and 5-17 families per trawl $l^{1}$. However, familial composition does differ somewhat, with Syllidae and Terebellidae amongst the most dominant families numerically, and families such as Maldanidae scarce relative to PGC samples. Furthermore, families that are moderately common in the EASIZ samples such as Glyceridae and Nereididae are totally absent from the PGC AGT samples. Maximum abundances also tended to be lower, with 43 syllid individuals the maximum recorded abundance in a single family for a single trawl, in contrast to individual counts of up to 173, 81, and 70 for Sternaspidae, Polynoidae, and Maldanidae respectively in PGC samples.

Closer to the PGC, several AGT trawls were taken from seabed formerly covered by Larsen A and B ice shelves during the expedition ANT-XXIII/8 RV on the Polarstern 2006/2007 (Gutt, 2008) as part of a larger study investigating the biodiversity of the then recently uncovered seabed (Gutt et al., 2011). Macrofaunal presence/absence data published show that several

\footnotetext{
${ }^{1}$ Excluding the deepest trawl that consisted of mud, which was sieved entirely through a $0.5 \mathrm{~mm}$ mesh screen, resulting in a maximum abundance of 2427 individuals in 20 families.
} 
named species identified in the current study were also present in these samples, such as Antarctinoe ferox, Antarctinoe spicoides, Austrolaeniella antarctica, Flabelligera mundata (synonym of Flabegraviera mundata), Harmothoe fuligineum, Harmothoe fullo, Maldane sarsi and Pista mirabilis (Gutt et al., 2010), 12 and 5 years after the collapse of the Larsen A and B ice shelves. The large flabelligerid Flabegraviera mundata, found at relatively high abundances at PGC Mid $850 \mathrm{~m}$, is also thought to have been observed under the Amery Ice shelf, East Antarctica, $100 \mathrm{~km}$ from open water (as Flabelligera mundata) (Riddle et al., 2007), however it is a relatively common species in the Southern Ocean with an assumed circumpolar distribution (though see section "Morphological Limitations and Future Molecular Work").

\section{Morphological Limitations and Future Molecular Work}

This study provides a good preliminary assessment of polychete communities in the Prince Gustav channel in terms of broad dominant functional groups present and taxonomic composition at the family level. The turnover in community structure and diversity is important to understand in a wider perspective; significantly increased burial of organic carbon caused by loss of ice cover and increased primary production has recently been reported from Antarctic areas (Barnes, 2015; Fogwill et al., 2020; Pineda-Metz et al., 2020; Rogers et al., 2020) but the role of the faunal response to changed nutrient availability and sedimentation rates are not known (Smith and DeMaster, 2008; Gogarty et al., 2020). However, diversity at the species level can be difficult to assess based on morphological identification alone.

Many of the named species identified in this study are considered to have widespread, circum-Antarctic distributions and broad depth ranges - a phenomenon well reported both for Southern Ocean polychetes and for Antarctic benthos in general (Schüller, 2011). The increasing use of molecular methods such as DNA barcoding in Antarctic sampling however is beginning to challenge this traditional notion (Grant et al., 2011), with numerous studies finding that many previously widespread species across several phyla are instead composed of cryptic species complexes (see Riesgo et al., 2015 and references therein) - morphologically similar yet genetically distinct species. In 2016, DNA barcoding of 16 Antarctic polychete morphospecies found evidence of cryptic diversity in over half the morphospecies examined, including taxa identified in the present study, such as Aglaophamus trissophyllus and Maldane sarsi (Brasier et al., 2016), suggesting that assessment based on morphology alone may significantly underestimate true species diversity. More recently, evidence of cryptic diversity has been found in Southern Ocean lineages of the polynoid Polyeunoa laevis (Bogantes et al., 2020), a taxon also present in the JR17003a samples.

A further consideration is the fact that traditional faunal lists and taxonomic identification literature available for Southern Ocean polychetes are considered to be outdated (Neal et al., 2018), with the presence of several globally widespread taxa with Northern Hemisphere type localities questionable. For example, the supposed cosmopolitan Maldane sarsi and its Antarctic subspecies Maldane sarsi antarctica Arwidsson, 1911 have both been reported from throughout the Southern Ocean (e.g., Hartman, 1966, 1967) - while the stem and subspecies differ primarily by color and gland pattern, these are not considered to be robust taxonomic characters (Wang and Li, 2016). However, Brasier et al. (2016) found that DNA barcode data of morphospecies identified as $M$. sarsi collected from Scotia and Amundsen seas differed from barcodes of $M$. sarsi collected from the stem species' type locality in northwestern Europe. The authors subsequently assigned their Antarctic morphospecies to M. sarsi antarctica, questioning whether the subspecies should be investigated as a separate morpho- or cryptic species given the genetic difference and geographic distance from the parent species, and querying the presence of the parent species in the Southern Ocean altogether. Maldane sarsi was amongst the most common morphospecies collected in the present study, with all morphotypes assigned to the parent taxon as a conservative approach until further assessment.

Annelids are also prone to fragmentation, and morphology cannot account for missing characters from damaged or incomplete specimens that could otherwise identify or delimit species. Although the preservation quality in the current study was high, the samples still included many posteriorly incomplete or damaged individuals, in addition to fragments without heads that were not included at all, but could be potentially be identified using DNA.

However, morphology can also overestimate species diversity. For example, the only two species of sternaspid polychetes described from the Southern Ocean, Sternaspis sendalli and Sternaspis monroi, were recently synonymized (the latter now the junior synonym) based on a molecular investigation that found little genetic structure between the two despite considerable variation in diagnostic morphological characters (Drennan et al., 2019). Furthermore, Polynoidae, the most morphospecies rich family in the current study, can display considerable degrees of intraspecific variation yet remain a single genetic species, as in the case of Harmothoe imbricata (Linnaeus, 1767) from waters off Scandinavia and Svalbard, which has at least ten distinct color morphs yet little genetic variation (Nygren et al., 2011). Additionally, juvenile polychetes can also show marked morphological differences from adult counterparts, and thus can often be misidentified as separate species when using morphology alone (Neal et al., 2014).

While molecular-based taxonomy can allow for a faster, statistically-rigorous assessment of diversity (though with its own caveats, see Riesgo et al., 2015), morphological assessments are still necessary in terms of providing information on life history, ecology, and ecosystem function, in addition to linking molecular results to described species and traditional premolecular taxonomic literature, and are a requisite for useful field identification guides (Glover et al., 2016). Molecular taxonomy should thus complement rather than supplant existing taxonomic methods (Bucklin et al., 2011). 
The morphospecies identified in the present study will be subject to future molecular taxonomic and connectivity analyses, which will include the DNA barcoding of all specimens; additional annelid specimens collected from the PGC sampling sites on the expedition JR170003a using both Epibenthic Sledge (EBS) and multi-corer sampling gear will also be included in these analyses. This will allow for a more thorough and comparable assessment of annelid diversity in the channel, for example through assessments of cryptic diversity and as an error check for morphological assignments. Furthermore, while the number of molecular investigations of Southern Ocean fauna have rapidly expanded in recent decades (Grant et al., 2011; Riesgo et al., 2015), major gaps in taxonomic and geographic coverage in terms of genetic data still exist, with annelids poorly represented relative to other groups such as Mollusca and Arthropoda (Riesgo et al., 2015), and regions of the Southern Ocean such as the Western Weddell Sea rarely sampled at all (Griffiths et al., 2014). Future molecular investigations of these samples will aid in filling these sampling gaps and will be included as part of wider phylogeographic and population genetic analyses assessing the connectivity, demographic history, and evolutionary origins of annelid fauna in this ice-influenced region. Understanding how the benthos of the Southern Ocean evolved and persisted through past environmental change over multimillion year timescales can provide insight into their resilience against current and future climactic change (Lau et al., 2020) and could inform current glacial and climactic models by providing an independent biological line of evidence for past ice sheet behavior (Strugnell et al., 2018).

\section{CONCLUSION}

This study provides a good snapshot of diverse benthic communities in a habitat with a dynamic recent glacial history and continuing glacial influence, which may be relevant to future habitats if present rates of ice loss and retreat along the Antarctic Peninsula continue. In addition, these specimens begin to fill sampling gaps in a poorly sampled region of the Southern Ocean and will be utilized in future molecular investigations, both in terms of assessing the genetic diversity of the channel and as part of wider phylogeographic and population genetic analyses of annelid fauna in this ice-influenced region. Curating accurate taxonomic and distributional data provides a necessary and important baseline for monitoring ecosystems and understanding current and future environmental change, while insights into the evolutionary history of the Southern Ocean benthos can help inform current climatic debate.

The channel is of further interest as its southern portion (south of $64^{\circ} \mathrm{N}$ ) is currently included within the margins of a proposed Marine Protected Area for the Weddell Sea, presented in 2014 to the Commission for the Conservation of Antarctic Marine Living Resources (CCAMLR), though as of 2018 has not yet been agreed upon (UN Ocean Conference, 2018). Increased knowledge of the fauna of this region may contribute to future decisions in regards to conservation policy implementation for the Weddell Sea area.

\section{DATA AVAILABILITY STATEMENT}

The original contributions presented in the study are included in the article and in Supplementary Material; the specimen biodiversity data generated in this study are publicly available online via the SCAR Antarctic Biodiversity Portal (biodiversity.aq) and can be accessed through the following doi: 10.15468/t223v4. A dataset of all JR17003a expedition Shallow Underwater Camera System (SUCS) imagery is available at doi: 10.5285/48DCEF16-6719-45E5-A335-3A97F099E451. Further inquiries can be directed to the corresponding author.

\section{AUTHOR CONTRIBUTIONS}

KL, AG, and TD developed and designed the study. AG, TD, and KL collected the samples. AG and TD sorted the samples and identified the specimens to family level in the field. RD performed morphological taxonomic analysis and identification of samples in the laboratory, prepared the figures and tables, performed analyses and drafted the original manuscript, which was critically revised by and improved by two reviewers. All authors contributed to the article and approved the submitted version.

\section{FUNDING}

This work was supported by the National Environment Research Council grants: RD has support by the NERC INSPIRE DTP (NE/S007210/1). KL is part of the British Antarctic Survey's Polar Science for Planet Earth Programme (NC-Science). TD was funded by the Norwegian Research Centre NORCE and the RSS James Clark Ross expedition JR17003a was funded by the NERC urgency grant NE/R012296/1 and enabled the participation of KL, AG, and TD.

\section{ACKNOWLEDGMENTS}

We would like to thank the Master and crew of RRS James Clark Ross and the scientific and technical participants of JR17003a for their support. Special thanks to Simon Dreuter for providing the bathymetric map. A special thank you also to Anton Van de Putte for their great assistance and guidance throughout the process of publishing data through biodiversity.aq. The fieldwork in the western Weddell Sea during JR17003a was undertaken under the permit No. 43/2017 issued by the Foreign and Commonwealth Office, London to section 3 of the Antarctic Act 1994.

\section{SUPPLEMENTARY MATERIAL}

The Supplementary Material for this article can be found online at: https://www.frontiersin.org/articles/10.3389/fmars.2020. 595303/full\#supplementary-material 


\section{REFERENCES}

Almond, P. (2019). Benthic Assemblage and Habitat Heterogeneity in the Prince Gustav Channel of the Antarctic Peninsula. Master's thesis, Newcastle University, Newcastle Upon Tyne.

Arnaud, P. M., López, C. M., Olaso, I., Ramil, F., Ramos-Esplá, A. A., and Ramos, A. (1998). Semi-quantitative study of macrobenthic fauna in the region of the South Shetland Islands and the Antarctic Peninsula. Polar Biol. 19, 160-166. doi: $10.1007 /$ s003000050229

Arntz, W., and Gutt, J. (1999). The expedition ANTARKTIS XV/3 (EASIZ II) of RV “Polarstern" in 1998. Ber. Polarforsch. 301:229.

Barnes, D., and Peck, L. (2008). Vulnerability of Antarctic shelf biodiversity to predicted regional warming. Clim. Res. 37, 149-163. doi: 10.3354/cr00760

Barnes, D. K. A. (2015). Antarctic sea ice losses drive gains in benthic carbon drawdown. Curr. Biol. 25, R789-R790. doi: 10.1016/j.cub.2015.07.042

Barnich, R., Gambi, M. C., and Fiege, D. (2012). Revision of the genus Polyeunoa McIntosh, 1885 (Polychaeta, Polynoidae). Zootaxa 3523, 25-38. doi: 10.11646/ zootaxa.3523.1.3

Bertolin, M. L., and Schloss, I. R. (2009). Phytoplankton production after the collapse of the Larsen A Ice Shelf, Antarctica. Polar Biol. 32, 1435-1446. doi: 10.1007/s00300-009-0638-x

Blake, J. A. (2015). New species of Scalibregmatidae (annelida, polychaeta) from the East Antarctic Peninsula including a description of the ecology and postlarval development of species of Scalibregma and Oligobregma. Zootaxa 4033, 57-93. doi: 10.11646/zootaxa.4033.1.3

Blake, J. A. (2017). Polychaeta orbiniidae from antarctica, the southern ocean, the abyssal pacific ocean, and off South America. Zootaxa 4218, 1-145. doi: 10.11646/zootaxa.4218.1.1

Blake, J. A. (2018). Bitentaculate Cirratulidae (Annelida, Polychaeta) collected chiefly during cruises of the R/V Anton Bruun, USNS Eltanin, USCG Glacier, R/V Hero, RVIB Nathaniel B. Palmer, and R/V Polarstern from the Southern Ocean, Antarctica, and off Western South A. Zootaxa 4537, 1-130. doi: 10. 11646/zootaxa.4537.1.1

Bogantes, V. E., Whelan, N. V., Webster, K., Mahon, A. R., and Halanych, K. M. (2020). Unrecognized diversity of a scale worm, Polyeunoa laevis (Annelida: Polynoidae), that feeds on soft coral. Zool. Scr. 49, 236-249. doi: 10.1111/zsc. 12400

Brachfeld, S., Domack, E., Kissel, C., Laj, C., Leventer, A., Ishman, S., et al. (2003). Holocene history of the Larsen - A Ice Shelf constrained by geomagnetic paleointensity dating. Geology 31, 749-752. doi: 10.1130/G19643.1

Brandt, A., Linse, K., and Schüller, M. (2009). Bathymetric distribution patterns of Southern Ocean macrofaunal taxa: bivalvia, Gastropoda, Isopoda and Polychaeta. Deep Sea Res. Part I Oceanogr. Res. Pap. 56, 2013-2025. doi: 10. 1016/J.DSR.2009.06.007

Brasier, M. J., Grant, S. M., Trathan, P. N., Allcock, L., Ashford, O., Blagbrough, H., et al. (2018). Benthic biodiversity in the South Orkney Islands Southern Shelf Marine Protected Area. Biodiversity 19, 5-19. doi: 10.1080/14888386.2018. 1468821

Brasier, M. J., Wiklund, H., Neal, L., Jeffreys, R., Linse, K., Ruhl, H., et al. (2016). DNA barcoding uncovers cryptic diversity in 50\% of deep-sea Antarctic polychaetes. R. Soc. Open Sci. 3:160432. doi: 10.1098/rsos.160432

Bucklin, A., Steinke, D., and Blanco-Bercial, L. (2011). DNA Barcoding of marine Metazoa. Annu. Rev. Mar. Sci. 3, 471-508. doi: 10.1146/annurev-marine120308-080950

Camerlenghi, A., Domack, E., Rebesco, M., Gilbert, R., Ishman, S., Leventer, A., et al. (2001). Glacial morphology and post-glacial contourites in northern Prince Gustav Channel (NW Weddell Sea, Antarctica). Mar. Geophys. Res. 22, 417-443. doi: 10.1023/A:1016399616365

Clarke, A., and Johnston, N. M. (2003). Antarctic marine benthic diversity. Oceanogr. Mar. Biol. Ann. Rev. 41, 47-114. doi: 10.1201/9780203180570-8

Cook, A. J., Fox, A. J., Vaughan, D. G., and Ferrigno, J. G. (2005). Retreating glacier fronts on the Antarctic Peninsula over the past half-century. Science 308, 541-544. doi: 10.1126/science. 1104235

Cook, A. J., and Vaughan, D. G. (2010). Overview of areal changes of the ice shelves on the Antarctic Peninsula over the past 50 years. Cryosphere 4, 77-98. doi: 10.5194/tc-4-77-2010

Cooper, A. P. R. (1997). Historical observations of Prince Gustav Ice Shelf. Polar Rec. 33, 285-294. doi: 10.1017/S0032247400025389
Cummings, V., Thrush, S., Norkko, A., Andrew, N., Hewitt, J., Funnell, G., et al. (2006). Accounting for local scale variability in benthos: implications for future assessments of latitudinal trends in the coastal Ross Sea. Antarct. Sci. 18, 633-644. doi: 10.1017/s0954102006000666

Dierssen, H. M., Smith, R. C., and Vernet, M. (2002). Glacial meltwater dynamics in coastal waters west of the Antarctic peninsula. Proc. Natl. Acad. Sci. U.S.A. 99, 1790-1795. doi: 10.1073/pnas.032206999

Domack, E., Leventer, A., Gilbert, R., Brachfeld, S., Ishman, S., Camerlenghi, A., et al. (2001). Cruise reveals history of Holocene Larsen Ice Shelf. Eos 82, 13-13. doi: 10.1029/01EO00009

Drennan, R., Wiklund, H., Rouse, G. W., Georgieva, M. N., Wu, X., Kobayashi, G., et al. (2019). Taxonomy and phylogeny of mud owls (Annelida: Sternaspidae), including a new synonymy and new records from the Southern Ocean, North East Atlantic Ocean and Pacific Ocean: challenges in morphological delimitation. Mar. Biodivers. 49, 2659-2697. doi: 10.1007/s12526-019-00 998-0

Drennan, R., Dahlgren, T. G., Linse, K., and Glover, A. G. (2020). Annelid Fauna of the Prince Gustav Channel, a previously ice-covered seaway on the northeastern Antarctic Peninsula - Data. SCAR - AntOBIS. Occur. Dataset 2020, 12-14. doi: 10.15468/t223v4 accessed via GBIF.org on 2020-12-14

Dreutter, S., Dorschel, B., and Linse, K. (2020). Swath sonar bathymetry data of RRS JAMES CLARK ROSS during cruise JR17003a with links to multibeam raw data. PANAGAEA 2020:EM122. doi: 10.1594/PANGAEA.916177

Eleftheriou, A., and Holme, N. A. (1984). "Macrofauna techniques," in Methods for the Study of Marine Benthos, eds N. A. Holme, et al. (Oxford: Blackwell Scientific Publications), 140-216.

Etourneau, J., Sgubin, G., Crosta, X., Swingedouw, D., Willmott, V., Barbara, L., et al. (2019). Ocean temperature impact on ice shelf extent in the eastern Antarctic Peninsula. Nat. Commun. 10:304. doi: 10.1038/s41467-018-08195-6

Evans, J., Pudsey, C. J., ÓCofaigh, C., Morris, P., and Domack, E. (2005). Late Quaternary glacial history, flow dynamics and sedimentation along the eastern margin of the Antarctic Peninsula Ice Sheet. Quat. Sci. Rev. 24, 741-774. doi: 10.1016/j.quascirev.2004.10.007

Ferrigno, J. G., Cook, A. J., Foley, K. M., Williams, R. S., Jr., Swithinbank, C., Fox, A. J., et al. (2006). Coastal-Change and Glaciological Map of the Trinity Peninsula Area and South Shetland Islands, Antarctica-1843-2001: U.S. Geological Survey Geologic Investigations Series Map I-2600-A, 1 map sheet, 32-p. Cambridge: British Antarctic Survey.

Fogwill, C. J., Turney, C. S. M., Menviel, L., Baker, A., Weber, M. E., Ellis, B., et al. (2020). Southern Ocean carbon sink enhanced by sea-ice feedbacks at the Antarctic Cold Reversal. Nat. Geosci. 13, 489-497. doi: 10.1038/s41561-0200587-0

Gambi, M. C., Castelli, A., and Guizzardi, M. (1997). Polychaete populations of the shallow soft bottoms off Terra Nova Bay (Ross Sea, Antarctica): distribution, diversity and biomass. Polar Biol. 17, 199-210. doi: 10.1007/s003000050123

Glover, G. A., Dahlgren, G. T., Wiklund, H., Mohrbeck, I., and Smith, R. C. (2016). An End-to-End DNA Taxonomy Methodology for Benthic Biodiversity Survey in the Clarion-Clipperton Zone, Central Pacific Abyss. J. Mar. Sci. Eng. 4:2. doi: 10.3390/jmse4010002

Gogarty, B., McGee, J., Barnes, D. K. A., Sands, C. J., Bax, N., Haward, M., et al. (2020). Protecting Antarctic blue carbon: as marine ice retreats can the law fill the gap? Clim. Policy 20, 149-162. doi: 10.1080/14693062.2019.1694482

Grant, R. A., Griffiths, H. J., Steinke, D., Wadley, V., and Linse, K. (2011). Antarctic DNA barcoding; a drop in the ocean? Polar Biol. 34, 775-780. doi: 10.1007/ s00300-010-0932-7

Griffiths, H., Van de Putte, A., Danis, B., De Broyer, C., Koubbi, P., Raymond, B., et al. (2014). "The data behind the Biogeographic Atlas of the Southern Ocean," in Proceedings of the EPIC32014 XXXIII SCAR Open Science Conference, Auckland.

Gutt, J. (2008). The expedition ANTARKTIS-XXIII/8 of the research vessel "Polarstern" in 2006/2007. Ber. Polar Meeresforsch. 569, 48-56.

Gutt, J., Barratt, I., Domack, E. W., d'Udekem d'Acoz, C., Dimmler, W., Grémare, A., et al. (2010). Macro benthos in surface sediments sampled during POLARSTERN cruise ANT-XXIII/8. PANGAEA. doi: 10.1594/PANGAEA. 718106. In supplement to: Gutt et al. (2011).

Gutt, J., Barratt, I., Domack, E., d’Udekem d'Acoz, C., Dimmler, W., Grémare, A., et al. (2011). Biodiversity change after climate-induced ice-shelf collapse in the Antarctic. Deep Sea Res. Part II 58, 74-83. doi: 10.1016/j.dsr2.2010.05.024 
Hartman, O. (1966). Polychaeta Myzostomidae and Sedentaria of Antarctica. Antartic Res. Ser. 7, 1-155. doi: 10.1029/AR007

Hartman, O. (1967). Polychaetous Annelids Collected by the USNS Eltanin and Staten Island Cruises, Chiefly from Antarctic Seas. Los Angeles, CA: University of Southern California.

Hilbig, B. (2004). Polychaetes of the deep Weddell and Scotia Seas - Composition and zoogeographical links. Deep Sea Res. Part II Top. Stud. Oceanogr. 51, 1817-1825. doi: 10.1016/j.dsr2.2004.07.015

Hilbig, B., Gerdes, D., and Montiel, A. (2006). Distribution patterns and biodiversity in polychaete communities of the Weddell Sea and Antarctic Peninsula area (Southern Ocean). J. Mar. Biolog. Assoc. 86, 711-725. doi: $10.1017 / \mathrm{s} 0025315406013610$

Johnson, J. S., Bentley, M. J., Roberts, S. J., Binnie, S. A., and Freeman, S. P. H. T. (2011). Holocene deglacial history of the northeast Antarctic Peninsula - A review and new chronological constraints. Quat. Sci. Rev. 30, 3791-3802. doi: 10.1016/j.quascirev.2011.10.011

Kaiser, S., Barnes, D. K. A., Sands, C. J., and Brandt, A. (2009). Biodiversity of an unknown Antarctic Sea: assessing isopod richness and abundance in the first benthic survey of the Amundsen continental shelf. Mar. Biodivers. 39, 27-43. doi: 10.1007/s12526-009-0004-9

Lau, S. C. Y., Wilson, N. G., Silva, C. N. S., and Strugnell, J. M. (2020). Detecting glacial refugia in the Southern Ocean. Ecography 43, 1639-1656. doi: 10.1111/ ecog. 04951

Linse, K., Brandt, A., Bohn, J. M., Danis, B., De Broyer, C., Ebbe, B., et al. (2007). Macro- and megabenthic assemblages in the bathyal and abyssal Weddell Sea (Southern Ocean). Deep Sea Res. Part II Top. Stud. Oceanogr. 54, 1848-1863. doi: 10.1016/J.DSR2.2007.07.011

Linse, K., Griffiths, H. J., Barnes, D. K. A., Brandt, A., Davey, N., David, B., et al. (2013). The macro- and megabenthic fauna on the continental shelf of the eastern Amundsen Sea, Antarctica. Cont. Shelf Res. 68, 80-90. doi: 10.1016/j. csr.2013.08.012

Linse, K., Grant, S., Whittle, R., Reid, W., McKenzie, M., Federwisch, L., et al. (2020). Benthic Seafloor Images from Prince Gustav Channel and Duse Bay, Eastern Antarctic Peninsula, March 2018 (Version 1.0) [Data set]. Cambridge: British Antarctic Survey.

Marchant, J. (2017). Giant iceberg's split exposes hidden ecosystem. Nature 549, 443-443. doi: $10.1038 / 549443$ a

Meredith, M. P., and King, J. C. (2005). Rapid climate change in the ocean west of the Antarctic Peninsula during the second half of the 20th century. Geophys. Res. Lett. 32:L19604. doi: 10.1029/2005GL024042

Morris, E. M., and Vaughan, D. G. (2003). "Spatial and temporal variation of surface temperature on the Antarctic peninsula and the limit of viability of ice shelves," in Antarctic Peninsula Climate Variability: Historical and Paleoenvironmental Perspectives, eds E. Domack, A. Levente, A. Burnet, R. Bindschadler, P. Convey, and M. Kirby (Washington, DC: American Geophysical Union), 61-68. doi: 10.1029/ar079p0061

Neal, L., Barnich, R., Wiklund, H., and Glover, A. G. (2012). A new genus and species of Polynoidae (Annelida, Polychaeta) from Pine Island Bay, Amundsen Sea, Southern Ocean-a region of high taxonomic novelty. Zootaxa 3542, 80-88. doi: 10.11646/zootaxa.3542.1.4

Neal, L., Linse, K., Brasier, M. J., Sherlock, E., and Glover, A. G. (2018). Comparative marine biodiversity and depth zonation in the Southern Ocean: evidence from a new large polychaete dataset from Scotia and Amundsen seas. Mar. Biodivers. 48, 581-601. doi: 10.1007/s12526-017-0735-y

Neal, L., Mincks Hardy, S., Smith, C., and Glover, A. (2011). Polychaete species diversity on the West Antarctic Peninsula deep continental shelf. Mar. Ecol. Prog. Ser. 428, 119-134. doi: 10.3354/meps09012

Neal, L., Wiklund, H., Muir, A. I., Linse, K., and Glover, A. G. (2014). The identity of juvenile Polynoidae (Annelida) in the Southern Ocean revealed by DNA taxonomy, with notes on the status of Herdmanella gracilis Ehlers sensu Augener. Mem. Mus. Vic. 71, 203-216. doi: 10.24199/j.mmv.2014. 71.16

Nicholls, K. W., Pudsey, C. J., and Morris, P. (2004). Summertime water masses off the northern Larsen C Ice Shelf, Antarctica. Geophys. Res. Lett. 31:L09309. doi: 10.1029/2004GL019924

Nolan, E. T., Barnes, D. K. A., Brown, J., Downes, K., Enderlein, P., Gowland, E., et al. (2017). Biological and physical characterization of the seabed surrounding
Ascension Island from 100-1000 m. J. Mar. Biolog. Assoc. 97, 647-659. doi: $10.1017 /$ S0025315417000820

Nordenskjöld, O. G., and Andersson, J. G. (1905). Antarctica. London: Hurst and Blackett.

Nygren, A., Norlinder, E., Panova, M., and Pleijel, F. (2011). Colour polymorphism in the polychaete Harmothoe imbricata (Linnaeus, 1767). Mar. Biol. Res. 7, 54-62. doi: 10.1080/17451001003713555

Nývlt, D., Košler, J., Mlcoch, B., Mixa, P., Lisá, L., Bubík, M., et al. (2011). The mendel formation: evidence for late miocene climatic cyclicity at the northern tip of the Antarctic Peninsula. Palaeogeogr. Palaeoclimatol. Palaeoecol. 299, 363-384. doi: 10.1016/j.palaeo.2010.11.017

Oksanen, J., Guillaume Blanchet, F., Friendly, M., Kindt, R., Legendre, P., McGlinn, D., et al. (2019). vegan: Community Ecology Package. Available online at: https: //cran.r-project.org/package=vegan (accessed July 9, 2020).

Parapar, J., López, E., Gambi, M. C., Núñez, J., and Ramos, A. (2011). Quantitative analysis of soft-bottom polychaetes of the Bellingshausen Sea and Gerlache Strait (Antarctica). Polar Biol. 34, 715-730. doi: 10.1007/s00300-010-0927-4

Pielou, E. C. (1969). An Introduction to Mathematical Ecology. New York, NY: Wiley.

Piepenburg, D., Schmid, M. K., and Gerdes, D. (2002). The benthos off King George Island (South Shetland Islands, Antarctica): further evidence for a lack of a latitudinal biomass cline in the Southern Ocean. Polar Biol. 25, 146-158. doi: $10.1007 /$ s003000100322

Pineda-Metz, S. E. A., Gerdes, D., and Richter, C. (2020). Benthic fauna declined on a whitening Antarctic continental shelf. Nat. Commun. 11:2226. doi: 10.1038/ s41467-020-16093-z

Post, A. L., Galton-Fenzi, B. K., Riddle, M. J., Herraiz-Borreguero, L., O’Brien, P. E., Hemer, M. A., et al. (2014). Modern sedimentation, circulation and life beneath the Amery Ice Shelf, East Antarctica. Cont. Shelf Res. 74, 77-87. doi: 10.1016/J.CSR.2013.10.010

Post, A. L., Lavoie, C., Domack, E. W., Leventer, A., Shevenell, A., and Fraser, A. D. (2017). Environmental drivers of benthic communities and habitat heterogeneity on an East Antarctic shelf. Antarct. Sci. 29, 17-32. doi: 10.1017/ S0954102016000468

Pudsey, C. J., and Evans, J. (2001). First survey of Antarctic sub-ice shelf sediments reveals mid-Holocene ice shelf retreat. Geology 29, 787-790. doi: 10.1130/00917613(2001)029<0787:fsoasi >2.0.co;2

Pudsey, C. J., Evans, J., Domack, E. W., Morris, P., and Del Valle, R. A. (2001). Bathymetry and acoustic facies beneath the former Larsen-A and Prince Gustav ice shelves, north-west Weddell Sea. Antarct. Sci. 13, 312-322. doi: 10.1017/ S095410200100044X

Pudsey, C. J., Murray, J. W., Appleby, P., and Evans, J. (2006). Ice shelf history from petrographic and foraminiferal evidence, Northeast Antarctic Peninsula. Quat. Sci. Rev. 25, 2357-2379. doi: 10.1016/j.quascirev.2006.01.029

Quartino, M. L., Klöser, H., Schloss, I. R., and Wiencke, C. (2001). Biomass and associations of benthic marine macroalgae from the inner Potter Cove (King George Island, Antarctica) related to depth and substrate. Polar Biol. 24, 349-355. doi: $10.1007 / \mathrm{s} 003000000218$

R Core Team (2019). R: A Language and Environment for Statistical Computing. Vienna: R Foundation for Statistical Computing.

Rack, W., and Rott, H. (2004). Pattern of retreat and disintegration of the Larsen B ice shelf, Antarctic Peninsula. Ann. Glaciol. 39, 505-510. doi: 10.3189/ 172756404781814005

Riddle, M. J., Craven, M., Goldsworthy, P. M., and Carsey, F. (2007). A diverse benthic assemblage $100 \mathrm{~km}$ from open water under the Amery Ice Shelf, Antarctica. Paleoceanography 22:PA1204. doi: 10.1029/2006PA001327

Riehl, T., and Kaiser, S. (2012). Conquered from the deep sea? A new deep-sea isopod species from the Antarctic shelf shows pattern of recent colonization. PLoS One 7:e49354. doi: 10.1371/journal.pone.0049354

Riesgo, A., Taboada, S., and Avila, C. (2015). Evolutionary patterns in Antarctic marine invertebrates: an update on molecular studies. Mar. Genomics 23, 1-13. doi: 10.1016/J.MARGEN.2015.07.005

Rignot, E., Jacobs, S., Mouginot, J., and Scheuchl, B. (2013). Ice-shelf melting around Antarctica. Science 341, 266-270. doi: 10.1126/science.1235798

Rogers, A. D., Frinault, B. A. V., Barnes, D. K. A., Bindoff, N. L., Downie, R., Ducklow, H. W., et al. (2020). Antarctic Futures: an assessment of climate-driven changes in ecosystem structure, function, and service 
provisioning in the Southern Ocean. Annu. Rev. Mar. Sci. 12, 87-120. doi: 10.1146/annurev-marine-010419-011028

Rott, H., Abdel Jaber, W., Wuite, J., Scheiblauer, S., Floricioiu, D., Van Wessem, J. M., et al. (2018). Changing pattern of ice flow and mass balance for glaciers discharging into the Larsen A and B embayments, Antarctic Peninsula, 2011 to 2016. Cryosphere 12, 1273-1291. doi: 10.5194/tc-12-1273-2018

Rott, H., Floricioiu, D., Wuite, J., Scheiblauer, S., Nagler, T., and Kern, M. (2014). Mass changes of outlet glaciers along the Nordensjköld Coast, northern Antarctic Peninsula, based on TanDEM-X satellite measurements. Geophys. Res. Lett. 41, 8123-8129. doi: 10.1002/2014GL061613

Rott, H., Skvarca, P., and Nagler, T. (1996). Rapid collapse of northern Larsen Ice Shelf, Antarctica. Science 271, 788-792. doi: 10.1126/science.271.5250. 788

Sahade, R., Lagger, C., Torre, L., Momo, F., Monien, P., Schloss, I., et al. (2015). Climate change and glacier retreat drive shifts in an Antarctic benthic ecosystem. Sci. Adv. 1:e1500050. doi: 10.1126/sciadv.1500050

Sañé, E., Isla, E., Gerdes, D., Montiel, A., and Gili, J. M. (2012). Benthic macrofauna assemblages and biochemical properties of sediments in two Antarctic regions differently affected by climate change. Cont. Shelf Res. 35, 53-63. doi: 10.1016/j. csr.2011.12.008

Scambos, T. A., Berthier, E., Haran, T., Shuman, C. A., Cook, A. J., Ligtenberg, S. R. M., et al. (2014). Detailed ice loss pattern in the northern Antarctic Peninsula: widespread decline driven by ice front retreats. Cryosphere 8, 21352145. doi: 10.5194/tc-8-2135-2014

Schüller, M. (2011). Evidence for a role of bathymetry and emergence in speciation in the genus Glycera (Glyceridae, Polychaeta) from the deep Eastern Weddell Sea. Polar Biol. 34, 549-564. doi: 10.1007/s00300-010-0913-x

Schüller, M., Ebbe, B., and Wägele, J. W. (2009). Community structure and diversity of polychaetes (Annelida) in the deep Weddell Sea (Southern Ocean) and adjacent basins. Mar. Biodivers. 39, 95-108. doi: 10.1007/s12526-009-0009-4

Shannon, C. E., and Weaver, W. (1949). The Mathematical Theory of Communication. Urbana, IL: University of Illinois.

Smale, D. A., and Barnes, D. K. A. (2008). Likely responses of the Antarctic benthos to climate-related changes in physical disturbance during the 21 st century, based primarily on evidence from the West Antarctic Peninsula region. Ecography 31, 289-305. doi: 10.1111/j.0906-7590.2008.05456.x

Smith, C. R., and DeMaster, D. J. (2008). Preface and brief synthesis for the FOODBANCS volume. Deep Sea Res. Part II Top. 55, 2399-2403. doi: 10.1016/ j.dsr2.2008.08.001

Strugnell, J. M., Pedro, J. B., and Wilson, N. G. (2018). Dating Antarctic ice sheet collapse: proposing a molecular genetic approach. Quat. Sci. Rev. 179, 153-157. doi: 10.1016/j.quascirev.2017.11.014

Thoma, M., Jenkins, A., Holland, D., and Jacobs, S. (2008). Modelling Circumpolar Deep Water intrusions on the Amundsen Sea continental shelf, Antarctica. Geophys. Res. Lett. 35:L18602. doi: 10.1029/2008GL034939

Turner, J., Colwell, S. R., Marshall, G. J., Lachlan-Cope, T. A., Carleton, A. M., Jones, P. D., et al. (2005). Antarctic climate change during the last 50 years. Int. J. Climatol. 25, 279-294. doi: 10.1002/joc.1130

UN Ocean Conference (2018). Marine Protected Area in the Weddell-Sea, Antarctica. Available online at: https://oceanconference.un.org/commitments/ ?id=16038 (accessed May 1, 2020).

Vaughan, D. G., Marshall, G. J., Connolley, W. M., Parkinson, C., Mulvaney, R., Hodgson, D. A., et al. (2003). Recent rapid regional climate warming on the Antarctic Peninsula. Clim. Change 60, 243-274. doi: 10.1023/A:1026021217991

Wang, Y., and Li, X. (2016). A new Maldane species and a new Maldaninae genus and species (Maldanidae, Annelida) from coastal waters of China. ZooKeys 2016, 1-16. doi: 10.3897/zookeys.603.9125

Conflict of Interest: The authors declare that the research was conducted in the absence of any commercial or financial relationships that could be construed as a potential conflict of interest.

Copyright (C) 2021 Drennan, Dahlgren, Linse and Glover. This is an open-access article distributed under the terms of the Creative Commons Attribution License (CC BY). The use, distribution or reproduction in other forums is permitted, provided the original author(s) and the copyright owner(s) are credited and that the original publication in this journal is cited, in accordance with accepted academic practice. No use, distribution or reproduction is permitted which does not comply with these terms. 